Article

\title{
Glycoconjugation of Betulin Derivatives Using Copper-Catalyzed 1,3-Dipolar Azido-Alkyne Cycloaddition Reaction and a Preliminary Assay of Cytotoxicity of the Obtained Compounds
}

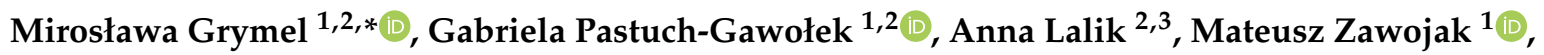 \\ Seweryn Boczek ${ }^{1}$, Monika Krawczyk ${ }^{1,2}{ }^{-1}$ and Karol Erfurt ${ }^{4}(\mathbb{D}$ \\ 1 Department of Organic Chemistry, Bioorganic Chemistry and Biotechnology, Silesian University of \\ Technology, B. Krzywoustego 4, 44-100 Gliwice, Poland; gabriela.pastuch@polsl.pl (G.P.-G.); \\ mateuszzawojak@wp.pl (M.Z.); seweryn.boczek16@gmail.com (S.B.); monika.krawczyk@polsl.pl (M.K.) \\ 2 Biotechnology Center, Silesian University of Technology, B. Krzywoustego 8, 44-100 Gliwice, Poland; \\ anna.lalik@polsl.pl \\ 3 Department of Systems Biology and Engineering, Silesian University of Technology, Akademicka 16, \\ 44-100 Gliwice, Poland \\ 4 Department of Chemical Organic Technology and Petrochemistry, Silesian University of Technology, \\ B. Krzywoustego 4, 44-100 Gliwice, Poland; karol.erfurt@polsl.pl \\ * Correspondence: miroslawa.grymel@polsl.pl; Tel.: +48-032-237-1873
}

Academic Editors: José Antonio Lupiáñez, Amalia Pérez-Jiménez and Eva E. Rufino-Palomares Received: 26 November 2020; Accepted: 16 December 2020; Published: 18 December 2020

\begin{abstract}
Pentacyclic lupane-type triterpenoids, such as betulin and its synthetic derivatives, display a broad spectrum of biological activity. However, one of the major drawbacks of these compounds as potential therapeutic agents is their high hydrophobicity and low bioavailability. On the other hand, the presence of easily transformable functional groups in the parent structure makes betulin have a high synthetic potential and the ability to form different derivatives. In this context, research on the synthesis of new betulin derivatives as conjugates of naturally occurring triterpenoid with a monosaccharide via a linker containing a heteroaromatic 1,2,3-triazole ring was presented. It has been shown that copper-catalyzed 1,3-dipolar azide-alkyne cycloaddition reaction (CuAAC) provides an easy and effective way to synthesize new molecular hybrids based on natural products. The chemical structures of the obtained betulin glycoconjugates were confirmed by spectroscopic analysis. Cytotoxicity of the obtained compounds was evaluated on a human breast adenocarcinoma cell line (MCF-7) and colorectal carcinoma cell line (HCT 116). The obtained results show that despite the fact that the obtained betulin glycoconjugates do not show interesting antitumor activity, the idea of adding a sugar unit to the betulin backbone may, after some modifications, turn out to be correct and allow for the targeted transport of betulin glycoconjugates into the tumor cells.
\end{abstract}

Keywords: betulin glycoconjugates; click chemistry; 1,3-dipolar cycloaddition; anticancer activity

\section{Introduction}

For several decades, natural products $(N P S)$ have been widely researched in terms of searching for potential therapeutic agents. One important class of natural plant products is pentacyclic lupane-type triterpenoids, among them betulin $(B N)$. In recent years, due to a strong biological activity and low toxicity, the great interest of scientists has been focused on its naturally occurring bioactive skeleton, as evidenced by numerous new semi-synthetic derivatives reported every year. Betulin (BN, 3-lup-20(29)-ene-3,28-diol) is cheap, easily accessible from natural resources, and can 
be readily extracted from the bark of several species of trees, especially from the white birch (Betula pubescens) [1,2]. BN possesses a broad spectrum of biological activity confirmed by its anticancer [3-13], antibacterial [14,15], anti-HIV [14,16], anti-inflammatory [17-19], antiviral [20,21], antimalarial activity $[17,19]$, and hepatoprotective properties [9,22,23].

One of the major drawbacks of betulin and analogs as potential therapeutic agents is its poor hydrophilicity, poor solubility in aqueous media like blood serum and polar solvents used for bioassays, and low bioavailability. However, due to the presence of easily transformable functional groups (including $\mathrm{C} 3 \mathrm{OH}, \mathrm{C} 28 \mathrm{OH}$ ) in the parent structure, betulin has a high synthetic potential and the ability to form numerous semisynthetic derivatives. Thus, the parent structure of betulin, being a biologically attractive scaffold with a high safety profile, makes it possible to carry out a variety of structural modifications to improve its pharmacokinetic properties. In some cases [5,6,9,12,24-26], the transformations gave compounds with a higher bioavailability and higher biological activity than the parent compound (Figure 1).
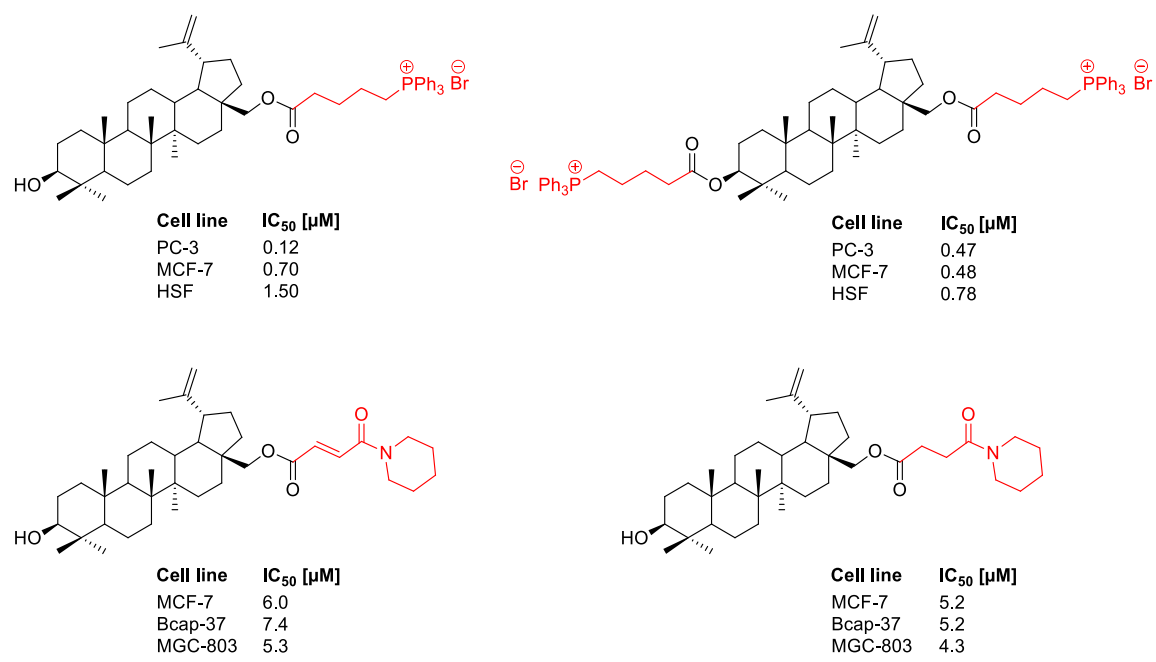

Figure 1. Antitumor activities of betulin derivatives against human breast carcinoma (MCF-7 and Bcap-37), human gastric carcinoma (MGC-803), human prostate carcinoma (PC-3), and human skin fibroblast (HSF) cell lines [12,27].

One of the strategies to improve the pharmacokinetic properties of betulin is its link to the 1,2,3-triazole ring, which is an important five-membered heterocyclic scaffold due to the extensive biological activities. This framework can be obtained through the copper-catalyzed azide-alkyne cycloaddition (CuAAC). In addition, the 1,2,3-triazole ring can be successfully used for conjugation in mild conditions and with high yields, with two or more molecules of interest. Due to the stability of triazoles in typical physiological conditions, they act as ideal linkers and could improve the hydrophilic property of the parent skeleton of NPs via the ability to create hydrogen bonding. The 1,2,3-triazole moiety mimics the naturally occurring amide bonds, and at the same time, it is more stable [28-31]. This methodology allows the functionalization of $B N$ at position C3, C28, and C30, with different substrate (Scheme 1). Although the triazole derivatives of betulin have been widely researched, no structures have been found so far that would demonstrate cytotoxicity at a level that would allow them to be used as drugs [32]. 


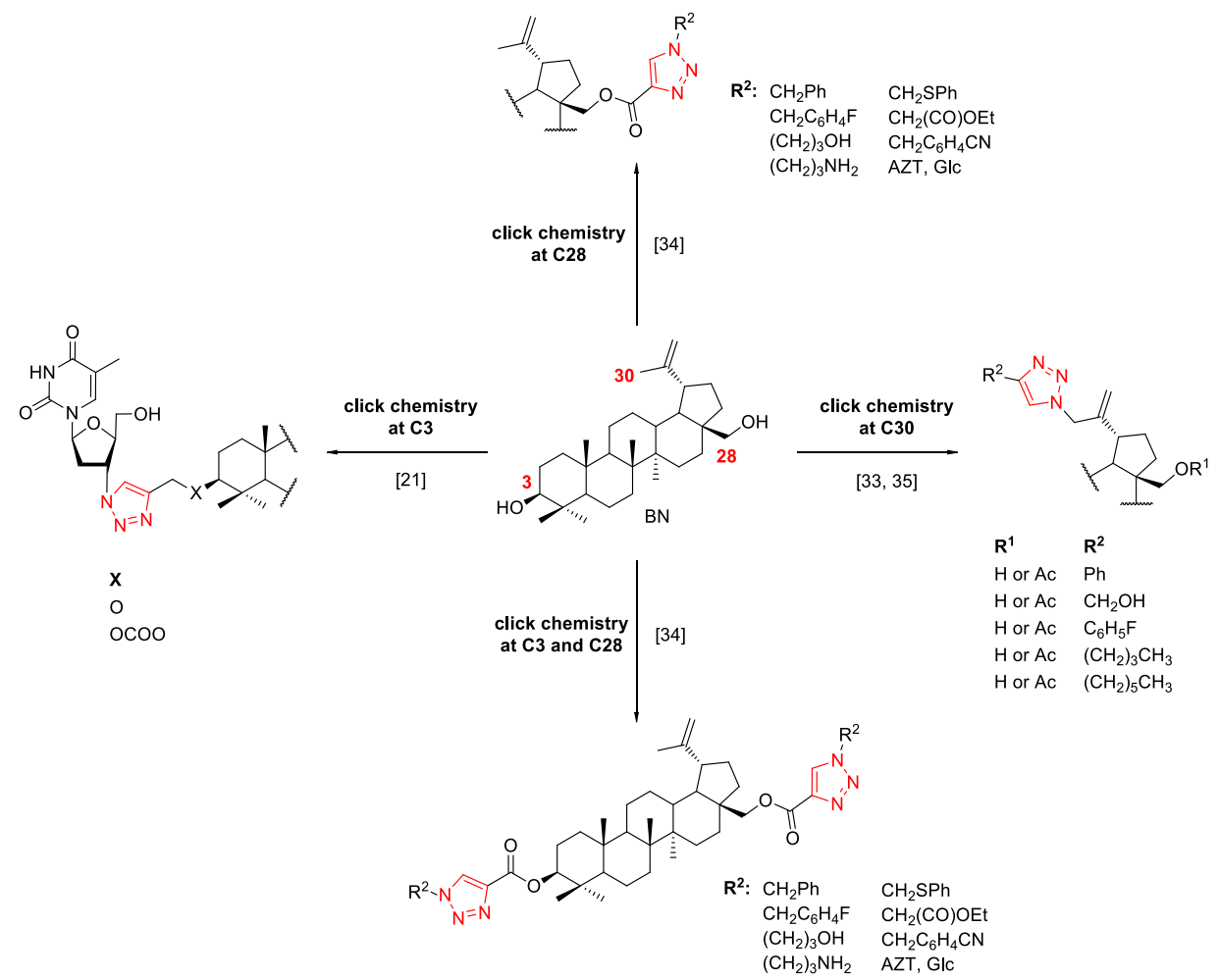

Scheme 1. Functionalization of betulin at the C3, C28, and C30 position via CuAAC [33-35].

The motivation for our research was the successes in the synthesis of molecular hybrids presented in Figure 2, obtained with the use of a natural biologically active compound, where the introduction of a triazole ring and a sugar unit into the parent structure of quinoline resulted in the improvement of pharmacological properties of the obtained glycoconjugates [36-39].
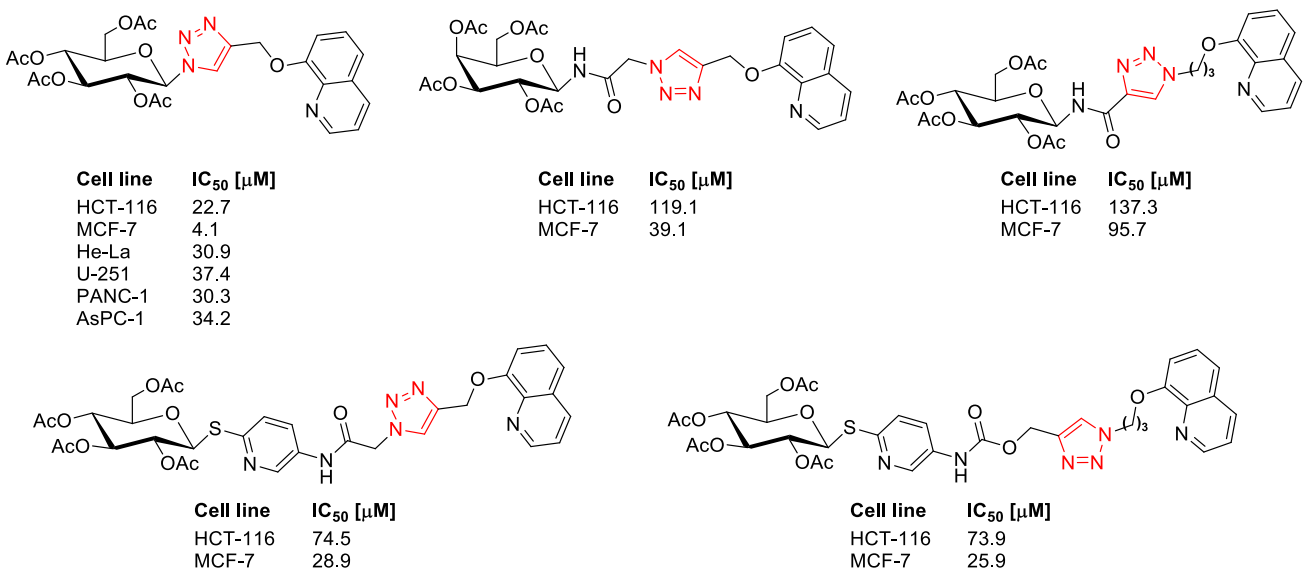

Figure 2. Selected quinoline glycoconjugates with anticancer activity.

The presence of a sugar unit in the hybrid molecules improves their pharmacokinetic properties, including solubility and intermembrane transport, as well as the selectivity in targeting drugs for a specific purpose. Sugar moieties are known to influence the pharmacokinetic properties of the respective compounds, such as absorption, distribution, and metabolism [40]. Since it is generally accepted that glycosides are more water soluble than the respective aglycones, glycosidation of triterpenes should increase hydrosolubility and improve the pharmacological properties. Furthermore, it is known that cancerous cells need a more significant sugar contribution than normal cells [41]. It is related to the specific metabolism of glucose by cancer cells as well as with their often-increased 
proliferation compared to healthy cells. This phenomenon is known as the Warburg effect and arises from mitochondrial metabolic changes. It consists in the fact that cancer cells produce their energy through glycolysis followed by lactic acid fermentation, characteristic of hypoxic conditions, and its level is much higher (more than 100 times) than in healthy cells, for which the main source of energy is mitochondrial oxidative phosphorylation [42]. An increased glycolysis process in cancer cells is associated with overexpression of GLUT transporters (special transmembrane proteins that facilitate concentration-dependent glucose uptake inside the cell) [43]. Consequently, this difference could be exploited to support the absorption of the therapeutic agent by the tumoral site, which allows for controlled drug delivery.

Our research group decided to focus on the synthesis of the new betulin glycoconjugates via click chemistry reaction. We designed semi-synthetic betulin derivatives as a combination of naturally occurring triterpenoid (BN) with proven broad biological activity, with a monosaccharide through a linker containing a heteroaromatic 1,2,3-triazole ring. The choice of the sugar unit for glycoconjugation was determined by the willingness to increase the selectivity of potential drugs by using the overexpression of GLUT transporters in some types of cancers. These transporters also recognize other sugars, such as galactose, mannose, and glucosamine [44]. It was decided to attach either D-glucose or D-galactose units due to the common occurrence of these sugars in nature. These sugars were supposed to perform the function of a drug carrier across the cell membrane by adapting to the structure of the GLUT transporter [43]. The configuration at the anomeric center of the sugar also seems important from the point of view of matching with the transporter. The results of research on the structural requirements for binding variously substituted sugars to the sugar transporters indicate that the $\beta$-configuration is preferred for binding to the GLUT transporters $[45,46]$. In order to obtain a library of compounds intended for the initial assessment of biological cytotoxicity, we tested two strategies for conjugating the sugar unit with the parent skeleton of betulin, both based on the 1,3-dipolar azido-alkyne cycloaddition reaction (Scheme 2).

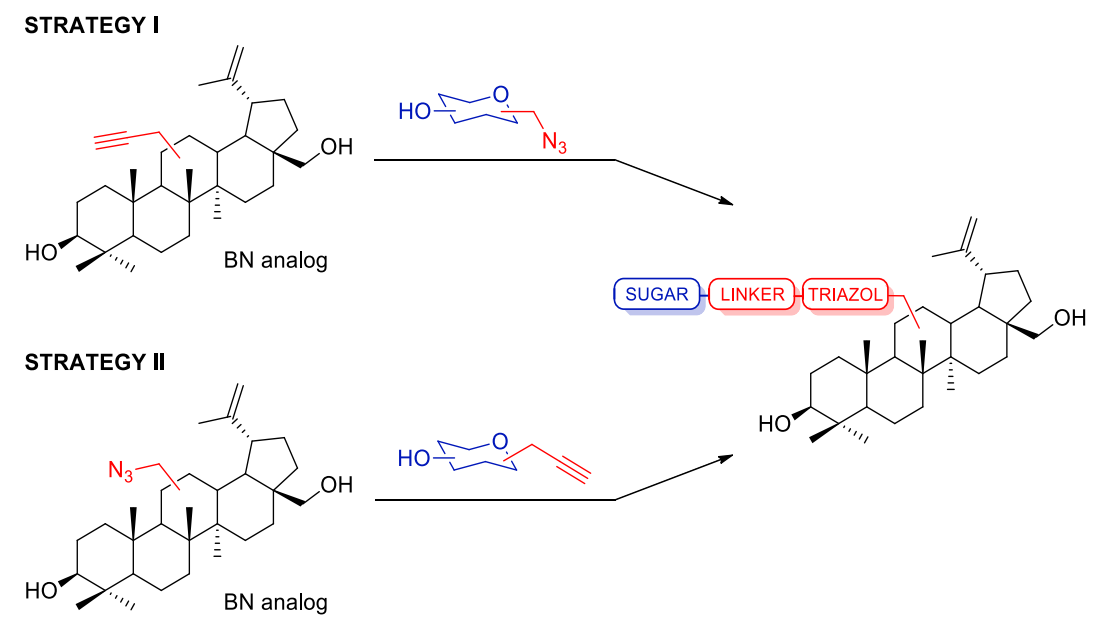

Scheme 2. Strategies for the synthesis of betulin glycoconjugates.

Strategy I involves the introduction of a propargyl moiety into the betulin structure at position C28 (monosubstituted betulin analogs) or C3 and C28 (disubstituted betulin analogs), followed by the synthesis of glycoconjugates containing the 1,2,3-triazole ring, resulting from combining propargyl betulin derivatives and appropriate sugar derivatives containing an azide moiety. Strategy II, on the other hand, consists of adding an appropriate linker $\left(\mathrm{O}(\mathrm{CO}) \mathrm{CH}_{2} \mathrm{~N}_{3}\right)$ to the betulin backbone one at position $\mathrm{C} 28$ or at two positions, $\mathrm{C} 3$ and $\mathrm{C} 28$, and the synthesis of glycoconjugates via click chemistry with the use of betulin azides and propargyl sugar derivatives. The linker that connects the betulin scaffold to the sugar unit is an important element that may influence the potential biological activity of the discussed betulin glycoconjugates. In this study, we report the synthesis of several glycoconjugates, 
having a linker containing a 1,2,3-triazole moiety and an additional ether ( $O$-glycosidic bond), ester, or amide moiety (Figure 3). The triazole ring seems to be an ideal linker component as it improves water solubility, thus allowing in vivo administration; it is analogous to an amide function for its electronic properties but simultaneously is resistant to hydrolysis, it is sufficiently stable in biological systems, and finally, it is rigid enough, which allows avoidance of internal interaction between the two linked moieties. On the other hand, the presence of a glycosidic, amide, or ester linkage gives a chance for the hydrolysis of the glycoconjugate into its biologically active components after the compound enters the cell under the action of hydrolytic enzymes. The cytotoxicity of the obtained compounds was evaluated on a human breast adenocarcinoma cell line (MCF-7) and colorectal carcinoma cell line (HCT 116).
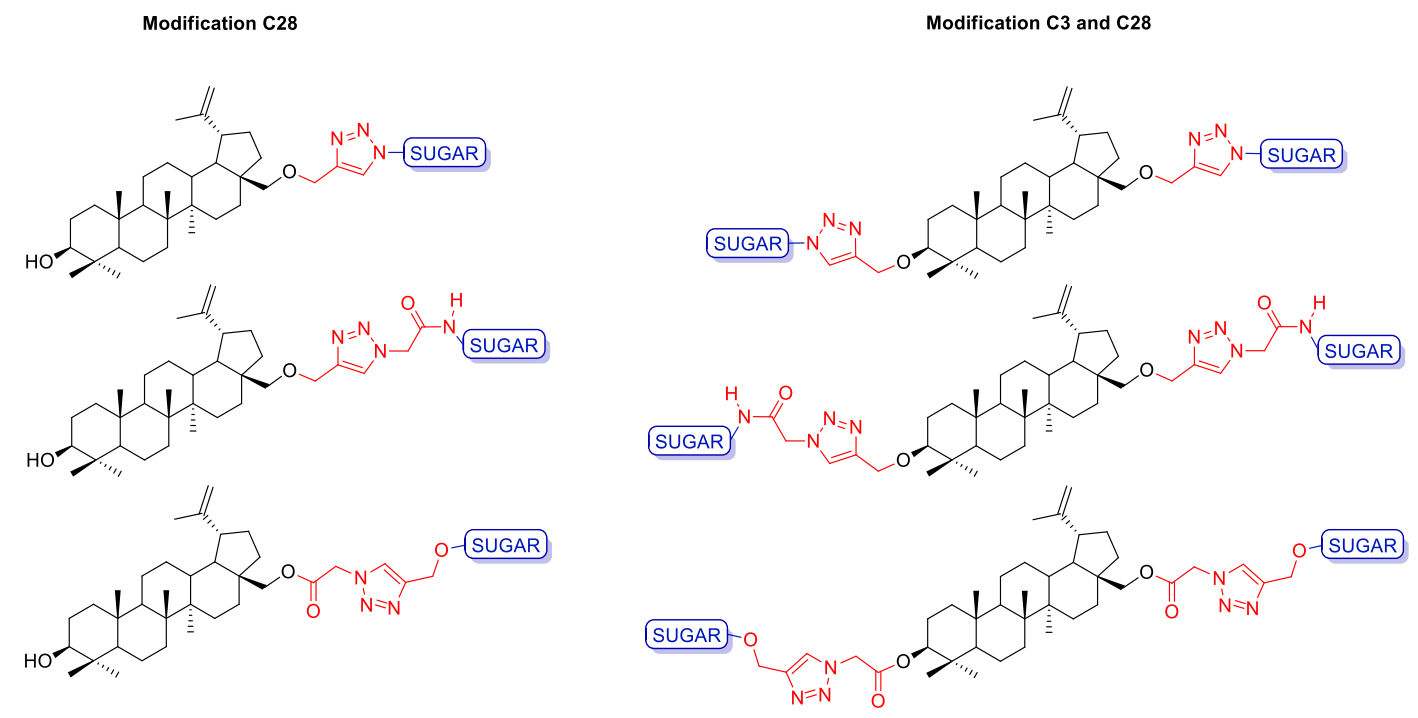

SUGAR $D$-glucose and $D$-galactose

Figure 3. General structure of the betulin glycoconjugates.

\section{Results and Discussion}

\subsection{Synthesis of Betulin Analogs}

The introduction of a propargyl moiety into the betulin molecule was based on the procedure described by Khan et al. for betulinic acid [47]. It was assumed that both mono- and dipropargyl derivatives of betulin could be formed due to the presence in the substrate of the primary $\mathrm{OH}$ group at the $\mathrm{C} 28$ position and the secondary $\mathrm{OH}$ group at the $\mathrm{C} 3$ position. The propargylated betulin was prepared as shown in Scheme 3. Crystalline betulin was reacted with propargyl bromide in alkaline medium $(\mathrm{NaH})$ in tetrahydrofuran. In the search for the optimal procedure, a number of modifications were made, by selecting the proportions of reagents, reaction time, and temperature. It was found that it is advantageous to use the reagents in a molar ratio $\left(\mathrm{BN} / \mathrm{NaH} / \mathrm{HC} \equiv \mathrm{CCH}_{2} \mathrm{Br}, 1: 4: 3.2\right)$ at ambient temperature for $24 \mathrm{~h}$.

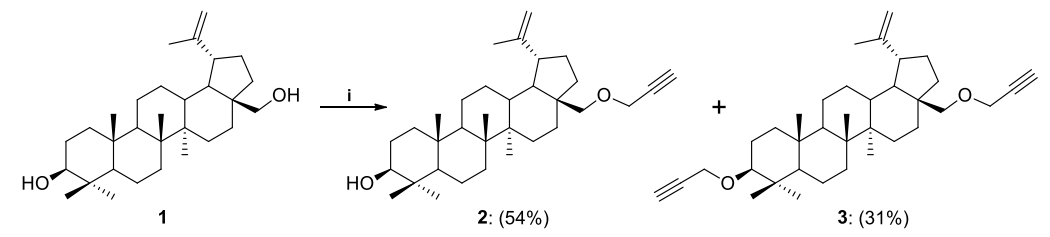

Scheme 3. Synthesis of propargyl derivatives of betulin 2 and 3. Reagents and Conditions: (i) propargyl bromide, $\mathrm{NaH}$, THF, r.t., 24 h. 
The synthesis of 28-O-chloroacetylbetulin 4 and 3,28-O, $O^{\prime}$-di(chloroacetyl)betulin 5 was performed by modifying the procedure described by Komissarova et al. in 2017 [48]. Chloroacetic chloride was added dropwise to the betulin solution in THF, while triethylamine $\left(\mathrm{Et}_{3} \mathrm{~N}\right)$ was replaced with $\mathrm{N}, \mathrm{N}$-diisopropylethylamine (DIPEA) and 4-(dimethylamino)pyridine (DMAP). We found that the application of twice the excess of chloroacetic chloride to BN results in the formation of only $3,28-O, O^{\prime}$-di(chloroacetyl)betulin 5 with a high yield $(95 \%$, Scheme 4$)$. On the other hand, when the reagents were used in a molar ratio $\left(\mathrm{Cl}(\mathrm{CO}) \mathrm{CH}_{2} \mathrm{Cl} / \mathrm{DIPEA} / \mathrm{DMAP}, 1.2: 1.5: 0.1\right)$, a modification of the betulin skeleton was observed at both the $\mathrm{C} 28$ and $\mathrm{C} 3$ positions. The maximum yield with which a monosubstituted product 4 can be obtained is $34 \%$. Replacement of the chlorine anion in betulin analogs 4 and 5 by azide moiety was performed at an elevated temperature $\left(90^{\circ} \mathrm{C}\right)$ using $\mathrm{NaN}_{3}$ and DMF as a solvent. 28-O-Azidoacetylbetulin 6 and 3,28-O, $O^{\prime}$-di(azidoacetyl)betulin 7 were purified by column chromatography to give pure compounds with $64 \%$ and $72 \%$ yields, respectively (Scheme 4 , Table 1).

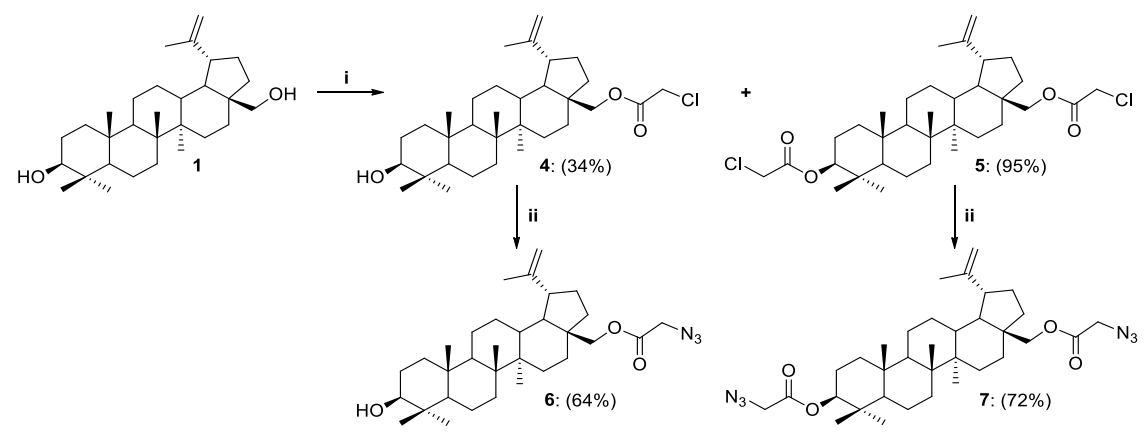

Scheme 4. Synthesis of betulin derivatives 4-7. Reagents and Conditions: (i) $\mathrm{Cl}(\mathrm{CO}) \mathrm{CH}_{2} \mathrm{Cl}$, DIPEA, DMAP, THF, r.t., 24 h; (ii) $\mathrm{NaN}_{3}, \mathrm{DMF}, 90^{\circ} \mathrm{C}, 3 \mathrm{~h}$.

Table 1. Synthesis of betulin derivatives 2-7.

\begin{tabular}{|c|c|c|c|c|c|c|c|c|}
\hline \multirow{2}{*}{ Entry } & \multicolumn{4}{|c|}{ Substrate } & \multicolumn{4}{|c|}{ Product } \\
\hline & No. & Solvent & Temp., ${ }^{\circ} \mathrm{C}$ & Time, h & No. & R (C3) & $R^{1}(C 28)$ & Yield, \% \\
\hline & & & & & 2 & $\mathrm{OH}$ & $\mathrm{OCH} 2 \mathrm{C} \equiv \mathrm{CH}$ & 54 \\
\hline 1 & 1 & THF & r.t. & 24 & 3 & $\mathrm{OCH} 2 \mathrm{C} \equiv \mathrm{CH}$ & $\mathrm{OCH} 2 \mathrm{C} \equiv \mathrm{CH}$ & 31 \\
\hline 2 & 1 & THF & r.t. & 24 & 4 & $\mathrm{OH}$ & $\mathrm{O}(\mathrm{CO}) \mathrm{CH} 2 \mathrm{Cl}$ & 34 \\
\hline 3 & 1 & THF & r.t. & 24 & 5 & $\mathrm{O}(\mathrm{CO}) \mathrm{CH} 2 \mathrm{Cl}$ & $\mathrm{O}(\mathrm{CO}) \mathrm{CH} 2 \mathrm{Cl}$ & 95 \\
\hline 4 & 4 & DMF & 90 & 3 & 6 & $\mathrm{OH}$ & $\mathrm{O}(\mathrm{CO}) \mathrm{CH} 2 \mathrm{~N} 3$ & 64 \\
\hline 5 & 5 & DMF & 90 & 3 & 7 & $\mathrm{O}(\mathrm{CO}) \mathrm{CH}_{2} \mathrm{~N} 3$ & $\mathrm{O}(\mathrm{CO}) \mathrm{CH} 2 \mathrm{~N} 3$ & 72 \\
\hline
\end{tabular}

\subsection{Synthesis of Sugar Derivatives}

Sugar derivatives substituted at the anomeric position were the second necessary structural element for the synthesis of betulin glycoconjugates. The synthetic route to the corresponding derivatives of D-glucose and D-galactose 9-14 is shown in Scheme 5. As mentioned before, the choice of such sugar moieties is dictated by the frequency of their natural occurrence as well as their importance for cell metabolism. All sugar derivatives were prepared according to known procedures involving the acetylation of free sugars $\mathbf{8 a}$ or $\mathbf{8 b}$ and conversion of per-O-acetylated derivatives $9 \mathbf{a}$ or $\mathbf{9 b}$ into the corresponding glycosyl bromides $\mathbf{1 1 a}$ or $\mathbf{1 1} \mathbf{b}[49,50]$. The glycosyl bromides were used for further reactions leading to obtain 2,3,4,6-tetra-O-acetyl- $\beta$-glycosyl azides 12a and 12b [36]. D-Glucose derivative 10a, in which the alkynyl moiety was introduced by the formation of an $O$-glycosidic linkage, was prepared by reacting per-O-acetylated D-glucose 9 a with propargyl alcohol in the presence of $\mathrm{BF}_{3} \cdot \mathrm{Et}_{2} \mathrm{O}$ as a Lewis acid catalyst [51]. Sugar derivatives $\mathbf{1 3 a}$ and $\mathbf{1 3} \mathbf{b}$ containing an amide moiety at the sugar anomeric position were obtained in a two-step procedure. First, glycosyl azides 12a and $\mathbf{1 2 b}$ were converted to the corresponding 1 -aminosugars through a hydrogenation reaction in a Parr apparatus using palladium hydroxide deposited on activated charcoal and then such obtained 
intermediates were reacted with chloroacetyl chloride in the presence of TEA, which neutralized the formed hydrogen chloride. Finally, the terminal chlorine atom in compounds 13a and 13b was exchanged with an azide group, which made it possible to obtain sugar derivatives $14 \mathbf{a}$ and $\mathbf{1 4 b}$ as a result of the reaction with sodium azide in anhydrous DMF [37].

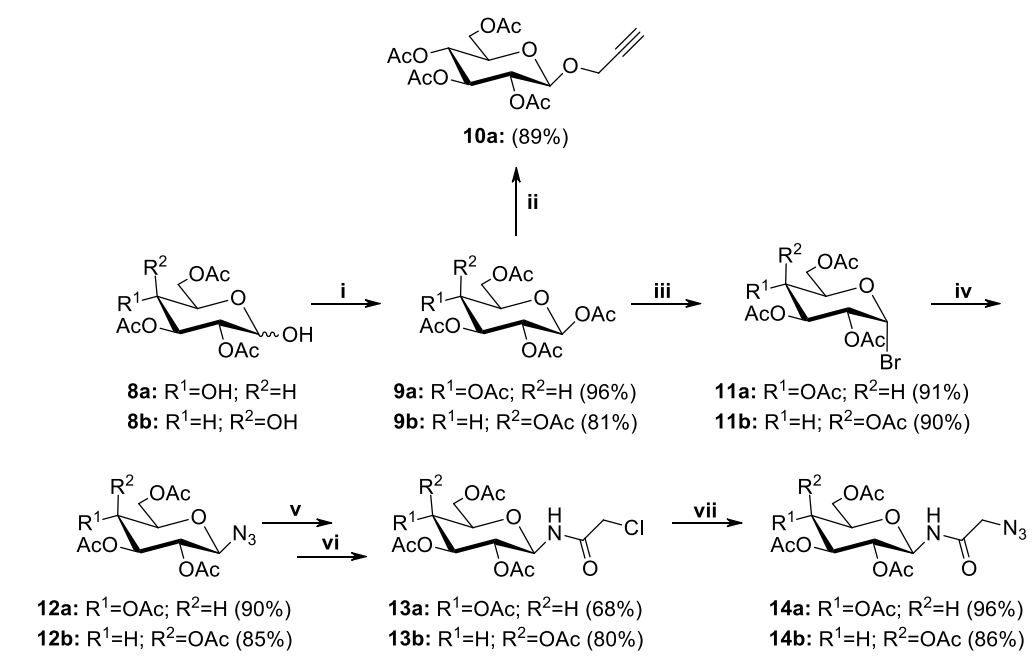

Scheme 5. Synthesis of sugar derivatives 9-14. Reagents and Conditions: (i) $\mathrm{CH}_{3} \mathrm{COONa}, \mathrm{Ac}_{2} \mathrm{O}$, b.p., $1 \mathrm{~h}$; (ii) propargyl alcohol, $\mathrm{BF}_{3} \cdot \mathrm{Et}_{2} \mathrm{O}, \mathrm{DCM}, 0{ }^{\circ} \mathrm{C} \rightarrow \mathrm{r.t}, 2 \mathrm{~h}$; (iii) $\mathrm{CH}_{3} \mathrm{COOH}, 33 \% \mathrm{HBr} / \mathrm{AcOH}$, r.t., 1 h; (iv) $\mathrm{NaN}_{3}, \mathrm{TBASH}, \mathrm{CHCl}_{3} / \mathrm{NaHCO}_{3}$, r.t., 2 h; (v) 20\% $\mathrm{Pd}(\mathrm{OH})_{2} / \mathrm{C}$, THF:EtOH (2:1, v/v), $\mathrm{H}_{2}, 1.5$ bar, 2 h; (vi) chloroacetyl chloride, TEA, DCM, r.t., 1 h; (vii) $\mathrm{NaN}_{3}$, DMF, r.t., 24 h.

\subsection{Modifications of the Natural Betulin Skeleton via Click Chemistry}

The copper-catalyzed azide-alkyne cycloaddition reaction (CuAAC) is widely used to modify natural bioactive compounds, and its main advantage is the ability to synthesize new molecular hybrids with high yields under mild conditions. In the course of our research, we developed a methodology for the synthesis of new previously unknown betulin derivatives, consisting of joining the triterpenoid skeleton with a monosaccharide through an appropriate linker containing a heteroaromatic 1,2,3-triazole ring. Glycoconjugation of betulin derivatives was based on the click chemistry reaction (CuAAC) using propargylbetulin derivatives 2, 3 and protected D-glucose 12a, 14a or D-galactose 12b, 14b derivatives containing an azide group (Strategy I, Schemes 6 and 7) or propargyl O-glycoside derivative of per-O-acetylated-D-glucose 10a with appropriate betulin azides 6, 7 (Strategy II, Scheme 8). Building blocks designed in this way make it possible to obtain a whole range of betulin glycoconjugates, containing in the linker structure different combinations of an O-glycosidic linkage, an ester bond, an O-methylene 1,2,3-triazole linker, and an amide moiety.

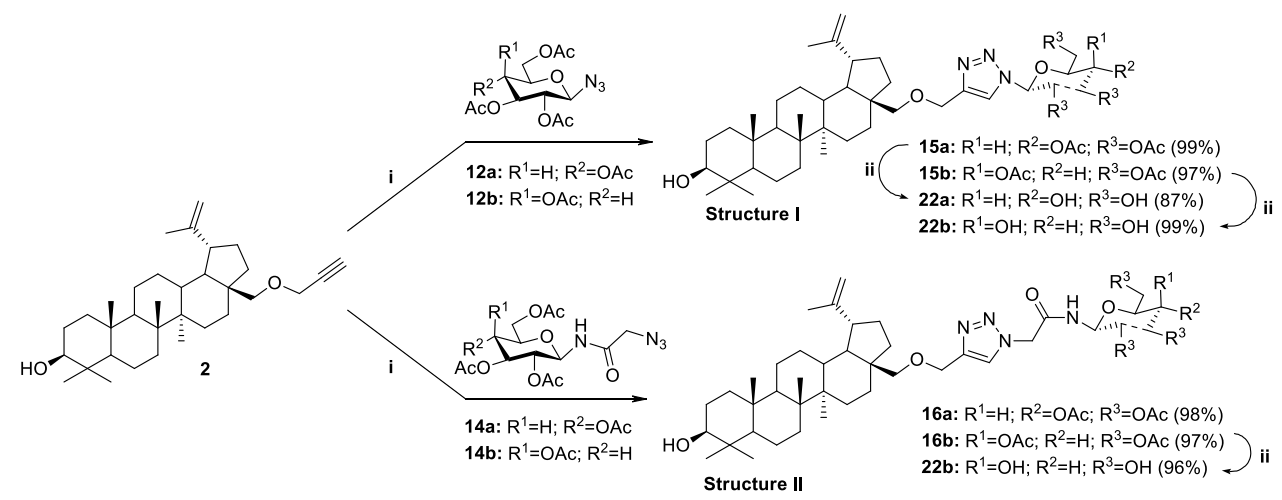

Scheme 6. Synthesis of glycoconjugates type I and II according to Strategy I. Reagents and Conditions: (i) $\mathrm{CuSO}_{4} \cdot 5 \mathrm{H}_{2} \mathrm{O}, \mathrm{NaAsc}, i-\mathrm{PrOH} / \mathrm{H}_{2} \mathrm{O}(1: 1, v / v)$, r.t., 24 h; (ii) 1 . $\mathrm{NaOMe}, \mathrm{MeOH}$, r.t., 0.5 h; 2 . Amberlyst-15. 


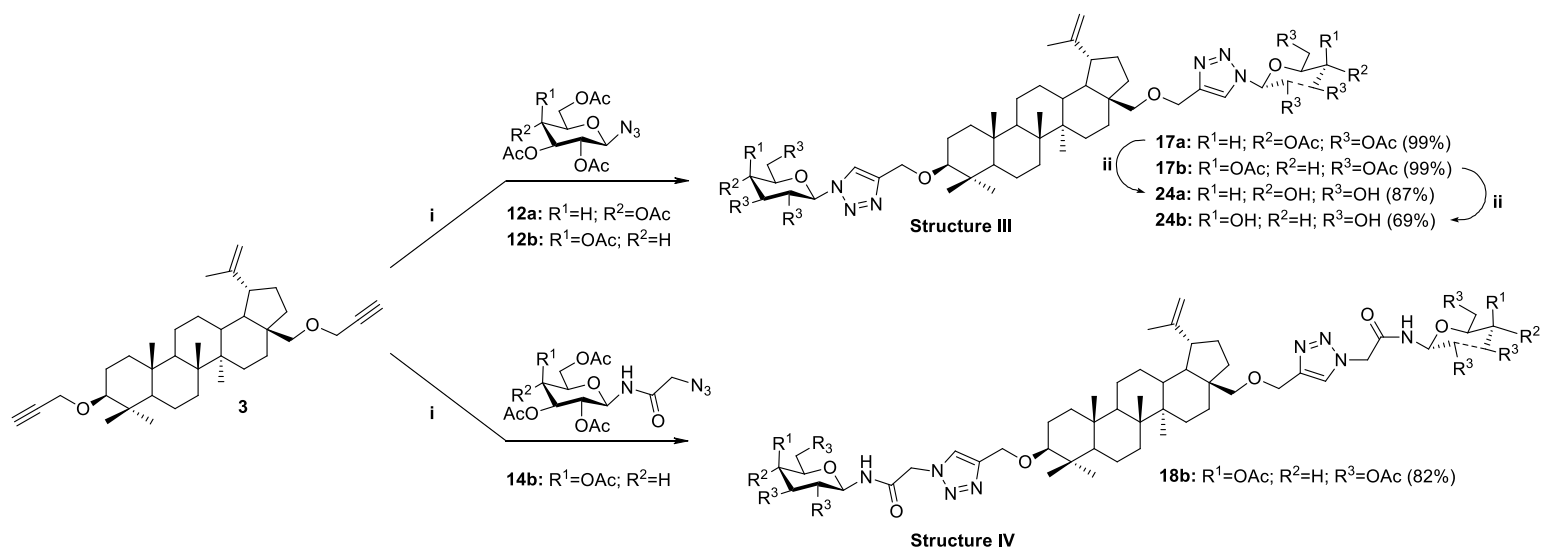

Scheme 7. Synthesis of glycoconjugates type III and IV according to Strategy I. Reagents and Conditions: (i) $\mathrm{CuSO}_{4} \cdot 5 \mathrm{H}_{2} \mathrm{O}, \mathrm{NaAsc}$, i-PrOH$/ \mathrm{H}_{2} \mathrm{O}(1: 1, v / v)$, r.t., 24 h; (ii) 1 . $\mathrm{NaOMe}, \mathrm{MeOH}$, r.t., 0.5 h:

2. Amberlyst-15.
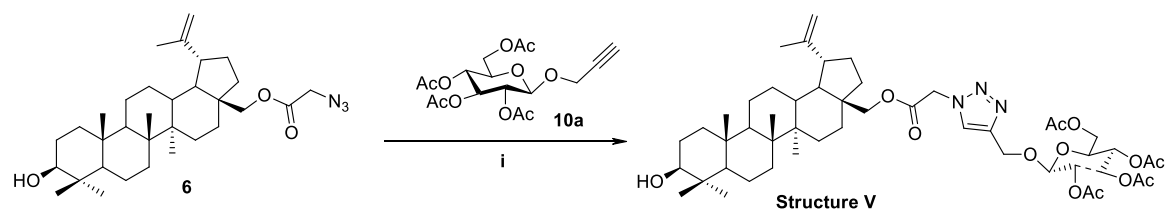

19a: $(97 \%)$

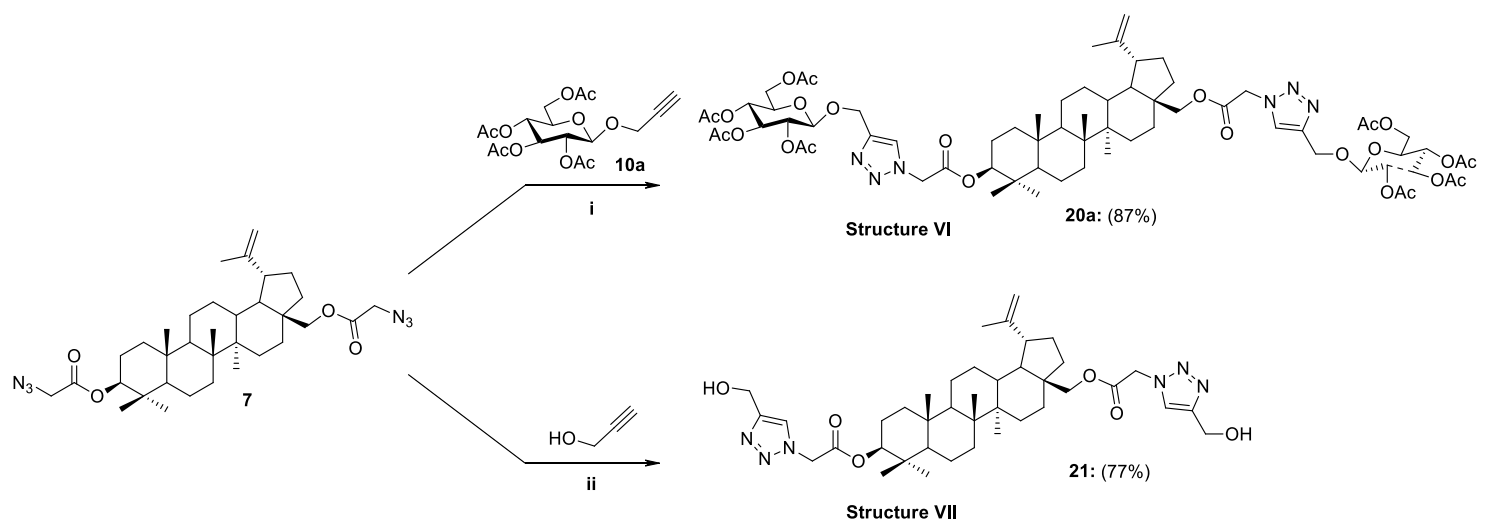

Scheme 8. Synthesis of glycoconjugates type V-VII according to Strategy II. Reagents and Conditions: (i) $\mathrm{CuSO}_{4} \cdot 5 \mathrm{H}_{2} \mathrm{O}, \mathrm{NaAsc}$, $i$ - $\mathrm{PrOH} / \mathrm{THF} / \mathrm{H}_{2} \mathrm{O}$, r.t., $24 \mathrm{~h}$, mol. ratio 6/10a/CuSO $4 \cdot 5 \mathrm{H}_{2} \mathrm{O} / \mathrm{NaAsc}$, 1:1:0.5:1.1; 7/10a/CuSO $4.5 \mathrm{H}_{2} \mathrm{O} / \mathrm{NaAsc}$, 1:2:1.1:0.6; (ii) propargyl alcohol, $\mathrm{CuSO}_{4} \cdot 5 \mathrm{H}_{2} \mathrm{O}, \mathrm{NaAsc}, i-\mathrm{PrOH} / \mathrm{THF} / \mathrm{H}_{2} \mathrm{O}$ (1.6:1:1.1, v/v/v), r.t., $24 \mathrm{~h}$, mol ratio $7 / \mathrm{C}_{3} \mathrm{H}_{4} \mathrm{O} / \mathrm{CuSO}_{4} \cdot 5 \mathrm{H}_{2} \mathrm{O} / \mathrm{NaAsc}$, 1:3:1.2:2.2.

The general procedure of glycoconjugation of betulin derivatives involves mixing of 28-O-propargylbetulin 2 or 3,28-O, $\mathrm{O}^{\prime}$-di(propargyl)betulin 3 with the appropriate monosugar derivative (D-glucose or D-galactose) in the water-alcohol solvent system $\left(i-\mathrm{PrOH} / \mathrm{H}_{2} \mathrm{O}\right)$. In the case of 28-O-azidoacetylbetulin 6 and 3,28-O,O'-di(azidoacetyl)betulin 7, due to the too low solubility of the substrates in the $i-\mathrm{PrOH} / \mathrm{H}_{2} \mathrm{O}$ solvent system, it was necessary to use an additional solvent (THF). In each case, the reaction was carried out under an argon atmosphere at room temperature for $24 \mathrm{~h}$, using $\mathrm{CuSO}_{4} \cdot 5 \mathrm{H}_{2} \mathrm{O}$ as a catalyst and sodium ascorbate (NaAsc) as an agent reducing $\mathrm{Cu}(\mathrm{II})$ to $\mathrm{Cu}(\mathrm{I})$.

As a result of the described reactions, five new monosubstituted betulin derivatives $(\mathbf{1 5 a}, \mathbf{1 5} \mathbf{b}, \mathbf{1 6} \mathbf{a}$, $\mathbf{1 6} \mathbf{b}$, and 19a) modified at position $C 28$, as well as four new disubstituted betulin derivatives $(\mathbf{1 7 a}, \mathbf{1 7} \mathbf{b}$, 18b, and 20a), modified at positions $C 3$ and $C 28$ were isolated by column chromatography in very good yields (97-99\% and $82-99 \%$, respectively, Table 2). 
Table 2. Summary synthesis of betulin glycoconjugates 15-24.

\begin{tabular}{|c|c|c|c|c|c|c|c|}
\hline \multirow{2}{*}{ Entry } & \multicolumn{4}{|c|}{ Substrate } & \multicolumn{3}{|c|}{ Product } \\
\hline & Analog BN & No. & Sugar & $\mathbf{R}^{1}, \mathbf{R}^{2}, \mathbf{R}^{3}$ & No. & Linker & Yield, \% \\
\hline \multicolumn{8}{|c|}{ STRATEGY I } \\
\hline 1 & 2 & $12 \mathrm{a}$ & Glc & OAc & $15 a$ & 28-OCH2Triaz & 99 \\
\hline 2 & 2 & $12 b$ & Gal & OAc & $15 \mathrm{~b}$ & 28-OCH2Triaz & 97 \\
\hline 3 & 2 & $14 \mathrm{a}$ & Glc & OAc & $16 a$ & 28-OCH2TriazCH2(CO)NH & 98 \\
\hline 4 & 2 & $14 \mathrm{~b}$ & Gal & OAc & $16 \mathrm{~b}$ & 28-OCH2TriazCH2(CO)NH & 97 \\
\hline 5 & 3 & $12 \mathrm{a}$ & Glc & OAc & $17 \mathrm{a}$ & 3,28-di-OCH2Triaz & 99 \\
\hline 6 & 3 & $12 b$ & Gal & OAc & $17 \mathrm{~b}$ & 3,28-di-OCH2Triaz & 99 \\
\hline 7 & 3 & $14 \mathrm{~b}$ & Gal & OAc & $18 \mathrm{~b}$ & 3,28-di-OCH2TriazCH2(CO)NH & 82 \\
\hline \multicolumn{8}{|c|}{ STRATEGY II } \\
\hline 8 & 6 & $10 \mathrm{a}$ & Glc & OAc & $19 a$ & 28-O(CO)CH2TriazCH2O & 97 \\
\hline 9 & 7 & $10 \mathrm{a}$ & Glc & OAc & $20 \mathrm{a}$ & 3,28-di-O(CO)CH2TriazCH2O & 87 \\
\hline 10 & 7 & - & - & - & 21 & 3,28-di-O(CO)CH2TriazOH & 77 \\
\hline \multicolumn{8}{|c|}{ DEPROTECTION } \\
\hline 11 & $15 a$ & - & Glc & $\mathrm{OH}$ & $22 \mathrm{a}$ & 28-OCH2Triaz & 87 \\
\hline 12 & $15 b$ & - & Gal & $\mathrm{OH}$ & $22 b$ & 28-OCH2Triaz & 99 \\
\hline 13 & $16 \mathrm{~b}$ & - & Gal & $\mathrm{OH}$ & $23 b$ & 28-OCH2TriazCH2(CO)NH & 96 \\
\hline 14 & $17 a$ & - & Glc & $\mathrm{OH}$ & $24 a$ & 3,28-di-OCH2Triaz & 87 \\
\hline 15 & $17 \mathrm{~b}$ & - & Gal & $\mathrm{OH}$ & $24 b$ & 3,28-di-OCH2Triaz & 69 \\
\hline
\end{tabular}

It has been considered that the use of an acyl protected sugar moiety may not be sufficient to achieve the desired hydrophilicity of the novel BN analogs. In order to compare the properties of glycoconjugates and assess the effect of acyl group presence, for the five per-O-acetylated glycoconjugates $\mathrm{BN}$ (15a, $15 b, 16 a, 16 b, 17 b)$, the deprotection of the sugar unit was performed by applying a standard Zemplén procedure [52], under mild conditions using $1 \mathrm{M}$ methanolic solution of sodium methoxide in methanol. The reaction was carried out at room temperature for $120 \mathrm{~min}$. The final step was to neutralize the reaction mixture with the use of Amberlyst-15 ion exchange resin, after which the mixture was filtered to give betulin glycoconjugates (22a, 22b, 23b, 24a) in high yield (87-99\%), except compound $\mathbf{2 4 b}(69 \%)$, as shown in Table 2.

Our proposed concept of adding a linker to the scaffold of betulin is based on introducing a chloroacetyl moiety into its structure and then converting the obtained analogs into azidoacetyl derivatives. In the case of the analog $\mathbf{2 1}$, in the final stage, the azide moiety was coupled with propargyl alcohol using the click chemistry reaction. As a result, a 3,28-disubstituted betulin 21 modified with a linker containing a 1,2,3-triazole ring substituted in the C4 position with a hydroxymethyl group was obtained in a yield of $77 \%$ (Scheme 8 ). The motivation to obtain a 3,28-O,O'-di(2-(4-(hydroxymethyl-1H-1,2,3-triazol-1-yl)acetyl)betulin 21 was the desire to check whether the addition of a sugar unit is necessary to improve the biological properties of $\mathrm{BN}$ or whether the introduction of the linker containing the 1,2,3-triazole ring alone would be sufficient. The structures of all synthesized compounds were confirmed by nuclear magnetic resonance $\left({ }^{1} \mathrm{H}-,{ }^{13} \mathrm{C}-\mathrm{NMR}, \mathrm{gHSQC}\right)$, infrared spectroscopy (FT-IR), and high-resolution mass spectrometry (HRMS).

\subsection{Cytotoxicity Studies}

The obtained betulin glycoconjugates were screened to determine their cytotoxicity. The research was conducted on two cell lines: HCT 116 (colorectal carcinoma cell line) and MCF-7 (human breast adenocarcinoma cell line). In these lines, overexpression of the glucose and galactose transporters was observed [53-55]. The aim of the research was to initially estimate the influence of the modifications of the parent betulin backbone by adding a sugar unit/units, as well as to examine the influence of the structure of linker connecting betulin with sugar on the cytotoxicity of the tested compounds.

In the first stage, betulin glycoconjugates in which the hydroxyl groups of the sugar unit were protected with acetyl groups were selected for research. The choice of the type of hydroxyl group protection was dictated by the sensitivity of acetyl groups to the action of hydrolytic enzymes and the 
fact that these groups provide glycoconjugates with increased hydrophobicity, which should facilitate passive transport into the cell. The proliferation of tumor cells (HCT 116, MCF-7) treated with tested compounds (15a, 15b, 16a, 17a, 17b, 19a) at 50- and 25- $\mu \mathrm{M}$ concentrations were determined after 24 and $48 \mathrm{~h}$ of incubation with the Cell Counting Kit-8 (CCK-8) based on the water-soluble tetrazole salt of WST-8. The CCK-8 kit, selected for the determination of viability and cytotoxicity, is less toxic and has higher sensitivity than other tetrazole salt-based tests, such as MTT or MTS [56]. The effect of these compounds was compared with the effect of betulin 1 doses, as shown in Figure 4.

(A)

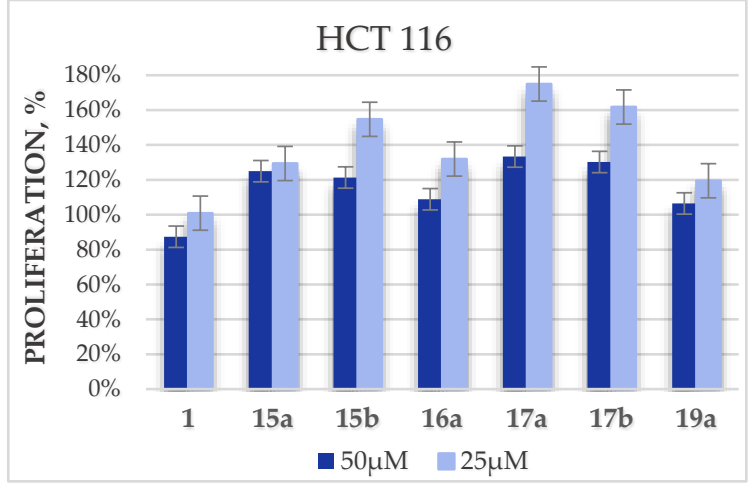

(C)

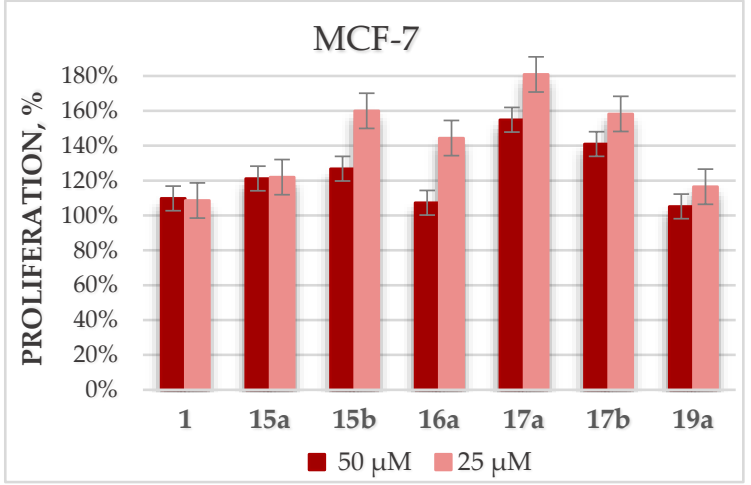

(B)

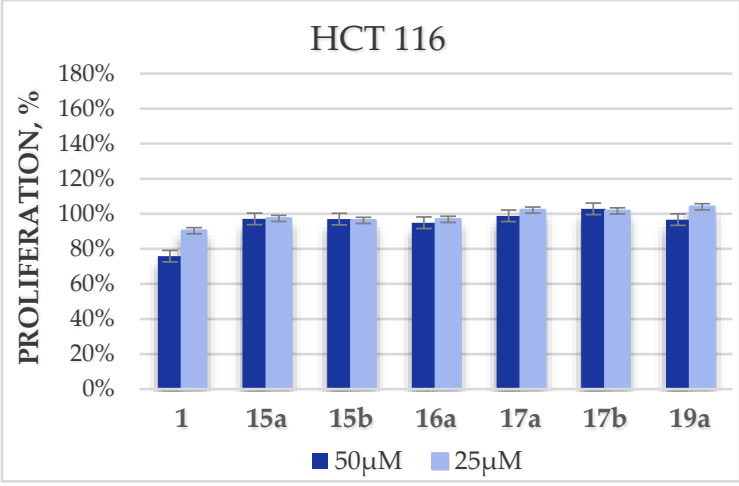

(D)

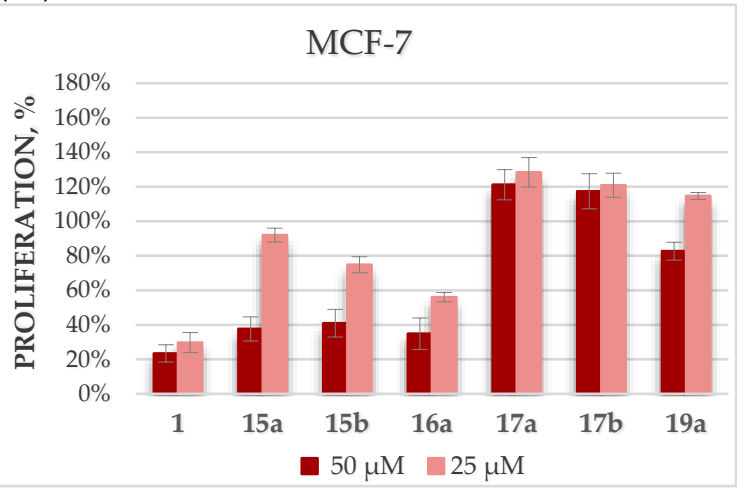

Figure 4. The dependence of HCT 116 and MCF-7 cell proliferation on the concentration of the betulin glycoconjugates, after $24(\mathbf{A}, \mathbf{C})$ or $48 \mathrm{~h}(\mathbf{B}, \mathbf{D})$ of incubation.

Unfortunately, in the case of the HCT 116 cell line, it was found that the designed betulin glycoconjugates, both at 24 and $48 \mathrm{~h}$, did not inhibit the proliferation of tumor cells. Additionally, it was observed that in some cases, the tested compounds even stimulate tumor cells to grow faster. It is especially visible after $24 \mathrm{~h}$ for analogs 15b, 17a, and 17b (Figure 4A). Our hypothesis explaining this fact is based on the assumption that these derivatives are able to enter cancer cells, where they are degraded by hydrolytic enzymes with the release of sugar molecules, which is an additional source of energy allowing the proliferation growth. In the case of the MCF-7 cell line, after $24 \mathrm{~h}$ of incubation with the tested glycoconjugates, a similar effect was observed as for the HCT 116 cell line. However, after $48 \mathrm{~h}$, a concentration-dependent cytotoxic effect of the glycoconjugates 15a, 15b, and 16a was observed (Figure 4D). These glycoconjugates, given to cells at the $50-\mu \mathrm{M}$ concentration, showed cytotoxicity comparable to that of betulin. In glycoconjugates 15a, 15b, and 16a, the betulin skeleton was modified at position $\mathrm{C} 28$ by adding a sugar unit via an O-methylene-1,2,3-triazole linker or the same linker extended with an $N$-methyleneamide group. Presumably, the protection of the sugar hydroxyl groups improved the passive transport of the glycoconjugates inside the cell, where they released betulin under the action of hydrolytic enzymes. In the case of the disubstituted analogs BN 17a and 17b, modified at both the $C 3$ and C28 positions, such a beneficial effect was not observed, 
which may be related to the prolonged effect of the release of as many as two glucose molecules (per each unit of betulin), which are the source of energy for increased proliferation. Quite unexpectedly, for the monosubstituted glycoconjugate 19a, no significant cytotoxic activity was observed on tumor cells. Perhaps, the ester bond connecting the betulin backbone with the sugar unit is too labile and some part of the compound undergoes hydrolysis even before it penetrates the cell.

In order to check whether the introduction of the sugar unit increases the affinity of the obtained molecules for GLUT transporters, the acetyl protections in the sugar fragment of the obtained glycoconjugates were removed, and then cytotoxicity tests of the obtained compounds were carried out on the same cell lines (HCT 116, MCF-7). The cytotoxicity of the disubstituted BN derivative 21, in which a linker contains only the 1,2,3-triazole system, without a sugar unit, was also tested. This study was designed to check the influence of the presence of the 1,2,3-triazole ring on the activity of the betulin derivative.

When the research was carried out on the HCT 116 cell line, both after $24 \mathrm{~h}$ and after $48 \mathrm{~h}$, no significant effect of inhibition of tumor cell proliferation by the tested glycoconjugates was observed (22a, 22b, 23b $, \mathbf{2 4 a}, \mathbf{2 4 b}$ ). Interestingly, derivative 21 after $48 \mathrm{~h}$ shows slightly higher cytotoxicity compared to the activity of the parent BN backbone (Figure 5B). In the case of the MCF-7 cell line, after $24 \mathrm{~h}$ of incubation, the effect caused by the glycoconjugates $(\mathbf{2 2 a}, \mathbf{2 2} \mathbf{b}, \mathbf{2 3 \mathbf { b }}, \mathbf{2 4 a})$ is only slightly better than that observed with BN. However, already after $48 \mathrm{~h}$ of incubation, the significantly higher cytotoxic activity of BN was observed compared to glycoconjugates. Surprisingly, as was in the case with the HCT 116 cell line, BN derivative 21 without a sugar unit, but only with an attached linker with the 1,2,3-triazole system, proved to be the most active. After $48 \mathrm{~h}$ of incubation, only $20 \%$ cell proliferation for this compound was observed as shown in Figure 5D.

(A)

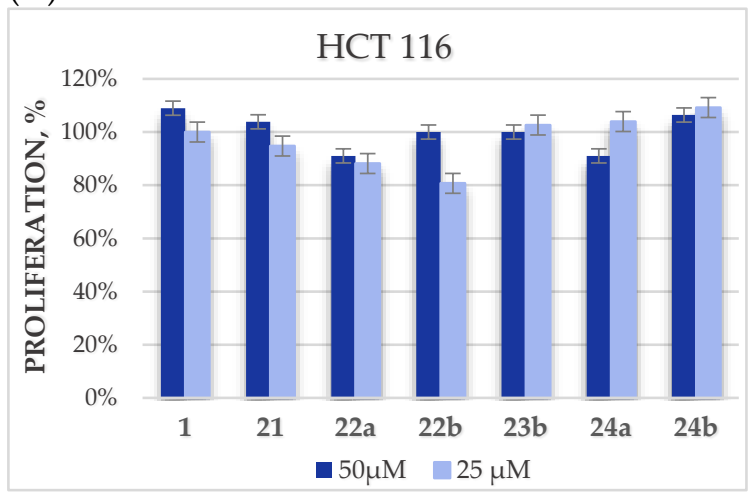

(C)

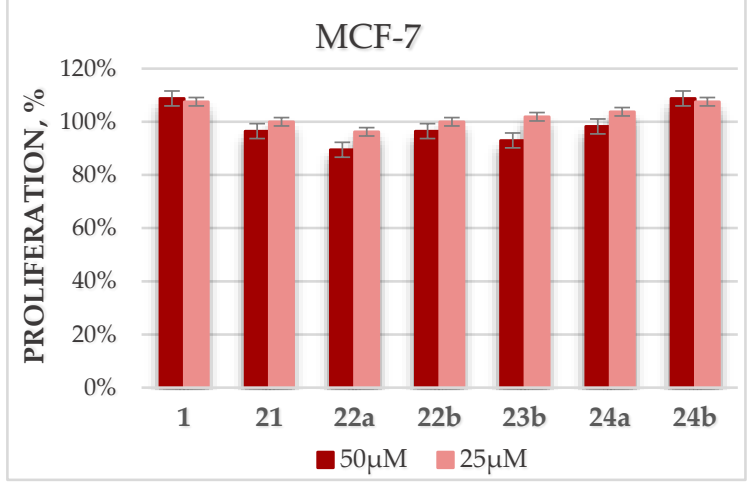

(B)

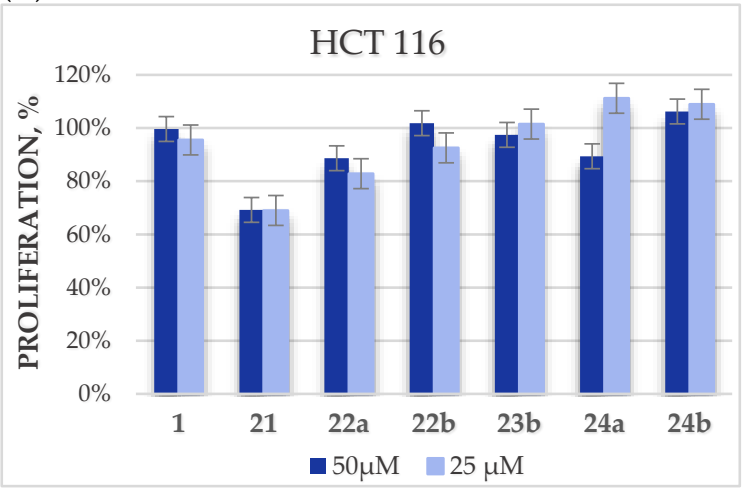

(D)

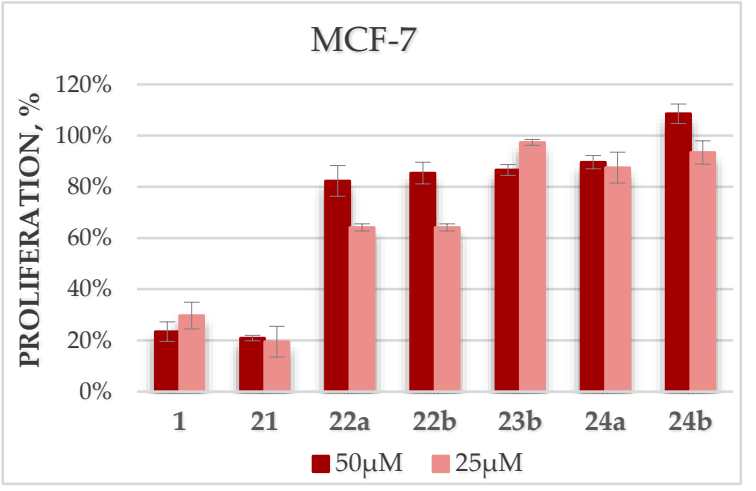

Figure 5. The dependence of HCT 116 and MCF-7 cell proliferation on the concentration of the betulin glycoconjugates, after $24(\mathbf{A}, \mathbf{C})$ or $48 \mathrm{~h}(\mathbf{B}, \mathbf{D})$ of incubation. 
In the course of further studies, for betulin 1 and its derivatives 15a, 15b, 16a, and 21, the ability to inhibit the proliferation of MCF-7 cells in a wider spectrum of concentrations was carried out in order to determine their $\mathrm{IC}_{50}$ value. The same compounds were also tested against NHDF cell line (normal human dermal fibroblast-neonatal cells), to assess the safety of their uses. Assays were performed in the concentration range of $50-6.25 \mu \mathrm{M}$ for both tested cell lines. Unfortunately, it turned out that glycoconjugates 15a, 15b, and 16a are equally cytotoxic in relation to healthy cells and to the tested tumor lines (Table 3). Additionally, the most active of betulin derivative 21, even at the lowest tested dose, is extremely cytotoxic and allows the proliferation of both cell lines to be kept at only $20 \%$. The cytotoxicity of compound 21 significantly exceeds that of betulin, which may suggest that further modification of this compound is necessary to improve its selectivity.

Table 3. Summary of cytotoxicity of BN and the betulin glycoconjugates.

\begin{tabular}{ccc}
\hline \multirow{2}{*}{ Compound } & \multicolumn{2}{c}{ Activity IC $_{\mathbf{5 0}}[\boldsymbol{\mu M}]^{\mathrm{a}, \mathrm{b}}$} \\
\cline { 2 - 3 } & MCF-7 & NHDF \\
\hline 1 & $12.40 \pm 0.14$ & $11.60 \pm 0.22$ \\
$15 \mathrm{a}$ & $65.28 \pm 0.68$ & $60.62 \pm 0.64$ \\
$15 \mathrm{~b}$ & $47.70 \pm 0.72$ & $47.61 \pm 0.86$ \\
$16 \mathrm{a}$ & $29.77 \pm 0.52$ & $29.82 \pm 0.45$ \\
\hline Cytotoxicity was evaluated using the CCK-8 assay; ${ }^{\mathrm{b}}$ Incubation time $48 \mathrm{~h}$.
\end{tabular}

\subsection{Cytotoxic Activity Predicted Lipophilicity}

In medicinal chemistry, the aqueous solubility and lipophilicity of a drug are important molecular parameters determining the absorption and the bioavailability. The lipophilicity is indicated by the logarithm of a partition coefficient $(\log \mathrm{P})$, which reflects the concentration ratio of the drug at equilibrium partitioning between octanol and water phases $[57,58]$.

Betulin 1, which is the subject of our research, is characterized by a highly limited solubility in polar solvents. This property may result from the complex structure, the presence of five fused aliphatic rings, and the isopropenyl moiety. The only polar fragments of the molecule are the two hydroxyl groups at C3 and C28. In this study, in order to determine the effect of various substituents on the value of the $\log \mathrm{P}$ coefficient for several betulin derivatives, we used the prediction base MolInspirations to evaluate in silico the parameter (Table 4).

As we expected, adding a sugar moiety decreases the lipophilicity $(<\log \mathrm{P})$ of betulin analogs. Moreover, in the case of triazole derivatives of betulin modified with a sugar unit, the difference was revealed when the structures containing a per-O-acetylated sugar unit 15-20 and an unprotected sugar unit 22-24 were compared. The linker type is also crucial. For compounds bearing a substituent of the $\mathrm{OCH}_{2}$ TriazGlc/Gal type at $\mathrm{C} 3$ and $\mathrm{C} 28$ position, the $\log \mathrm{P}$ values are higher than for compounds bearing substituents with an ester moiety in the same position. On the other hand, the lowest values of the coefficient have derivatives in which an amide group is present in the linker structure. Only betulin glycoconjugates $\mathbf{2 3}$ and $\mathbf{2 4}$ have $\log \mathrm{P}$ values smaller than 5 (Figure 6). 
Table 4. LogP of BN and betulin analogs 2-24.

\begin{tabular}{|c|c|c|c|}
\hline No. & $\mathrm{R}(\mathrm{C} 3)$ & $R^{1}(C 28)$ & $\log P$ \\
\hline 1 & $\mathrm{OH}$ & $\mathrm{OH}$ & 7.16 \\
\hline 2 & $\mathrm{OH}$ & $\mathrm{OCH} 2 \mathrm{C} \equiv \mathrm{CH}$ & 7.94 \\
\hline 3 & $\mathrm{OCH} 2 \mathrm{C} \equiv \mathrm{CH}$ & $\mathrm{OCH} 2 \mathrm{C} \equiv \mathrm{CH}$ & 8.54 \\
\hline 4 & $\mathrm{OH}$ & $\mathrm{O}(\mathrm{CO}) \mathrm{CH} 2 \mathrm{Cl}$ & 8.23 \\
\hline 5 & $\mathrm{O}(\mathrm{CO}) \mathrm{CH} 2 \mathrm{Cl}$ & $\mathrm{O}(\mathrm{CO}) \mathrm{CH} 2 \mathrm{Cl}$ & 8.86 \\
\hline 6 & $\mathrm{OH}$ & $\mathrm{O}(\mathrm{CO}) \mathrm{CH} 2 \mathrm{~N} 3$ & 8.31 \\
\hline 7 & $\mathrm{O}(\mathrm{CO}) \mathrm{CH} 2 \mathrm{~N} 3$ & $\mathrm{O}(\mathrm{CO}) \mathrm{CH} 2 \mathrm{~N} 3$ & 8.94 \\
\hline $15 \mathrm{a}$ & $\mathrm{OH}$ & OCH2TriazGlc $(\mathrm{OAc})$ & 7.59 \\
\hline $16 a$ & $\mathrm{OH}$ & OCH2TriazCH2(CO)NHGlc(OAc) & 6.69 \\
\hline $17 \mathrm{a}$ & OCH2TriazGlc(OAc) & OCH2TriazGlc(OAc) & 8.01 \\
\hline $18 \mathrm{~b}$ & OCH2TriazCH2(CO)NHGal(OAc) & OCH2TriazCH2(CO)NHGal(OAc) & 6.22 \\
\hline $19 \mathrm{a}$ & $\mathrm{OH}$ & $\mathrm{O}(\mathrm{CO}) \mathrm{CH} 2$ TriazCH2OGlc(OAc) & 7.45 \\
\hline $20 \mathrm{a}$ & $\mathrm{O}(\mathrm{CO}) \mathrm{CH} 2$ TriazCH2OGlc(OAc) & $\mathrm{O}(\mathrm{CO}) \mathrm{CH} 2$ TriazCH2OGlc(OAc) & 7.74 \\
\hline 21 & $\mathrm{O}(\mathrm{CO}) \mathrm{CH} 2 \mathrm{TriazOH}$ & $\mathrm{O}(\mathrm{CO}) \mathrm{CH} 2 \mathrm{TriazOH}$ & 6.38 \\
\hline $22 \mathrm{a}$ & $\mathrm{OH}$ & OCH2TriazGlc(OH) & 5.21 \\
\hline $23 b$ & $\mathrm{OH}$ & OCH2TriazCH2(CO)NHGal(OH) & 4.31 \\
\hline $24 a$ & OCH2TriazGlc $(\mathrm{OH})$ & OCH2TriazGlc $(\mathrm{OH})$ & 3.25 \\
\hline
\end{tabular}

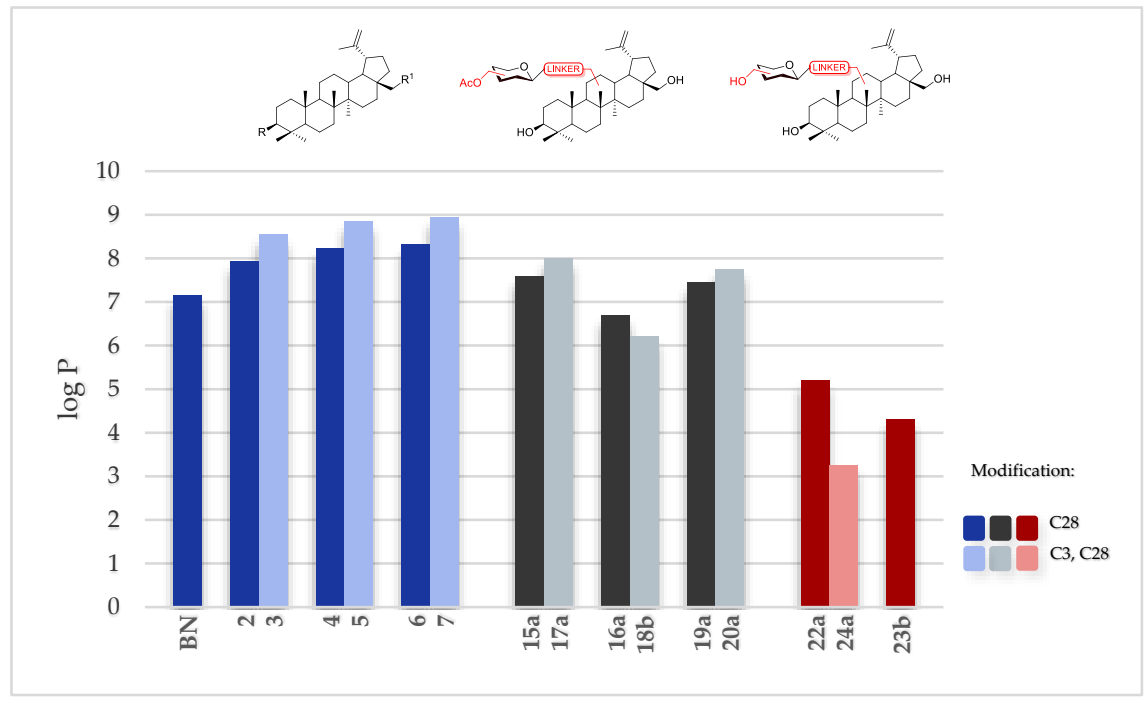

Figure 6. $\log \mathrm{P}$ of $\mathrm{BN}$ and betulin analogs 2-24.

\section{Materials and Methods}

\subsection{General Information}

NMR spectra were recorded on a Varian spectrometer at operating frequencies of 600 or 400 and 150 or $100 \mathrm{MHz}$, respectively, using TMS as the resonance shift standard and NMR solvents $\left(\mathrm{CDCl}_{3}\right.$, $\mathrm{CD}_{3} \mathrm{OD}$ or DMSO- $d_{6}$ ), which was purchased from ACROS Organics (Geel, Belgium). All chemical shifts $(\delta)$ are reported in ppm and coupling constants $(J)$ in Hz. The following abbreviations were used to explain the observed multiplicities: s: singlet, d: doublet, dd: doublet of doublets, ddd: doublet of doublet of doublets, $\mathrm{t}$ : triplet, $\mathrm{dd} \sim \mathrm{t}$ : doublet of doublets resembling a triplet (with similar values of coupling constants), m: multiplet, br: broad. IR-spectra were measured on an FTIR spectrophotometer 
(ATR method). High-resolution mass spectrometry (HRMS) analyses were performed on a Waters LCT Premier XE system using the electrospray-ionization (ESI) technique. Optical rotations were measured with a JASCO P-2000 polarimeter using a sodium lamp (589.3 nm) at room temperature. Melting points were determined using a Boethius M HMK hot-stage apparatus. Reactions were monitored by TLC on precoated plates of silica gel 60 F254 (Merck Millipore). TLC plates were inspected under UV light $(\lambda=254 \mathrm{~nm})$ or charring after spraying with $10 \%$ solution of sulfuric acid in ethanol. Crude products were purified using column chromatography performed on Silica Gel 60 (70-230 mesh, Fluka).

Cell viability was measured using a Cell Counting Kit-8 (Bimake) according to the manufacturer's protocol. The absorbance on the CKK-8 assay was measured spectrophotometrically at the 450-nm wavelength using a plate reader (Epoch, BioTek, USA).

28-O-Chloroacetylbetulin 4 and 3,28-O,O'-di(2-chloroacetyl)betulin 5 [48], 1,2,3,4,6-penta-Oacetyl- $\beta$-D-glucopyranose 9a, 1,2,3,4,6-penta- $O$-acetyl- $\beta$-D-galactopyranose 9b [53], propargyl 2,3,4,6-tetra-O-acetyl- $\beta$-D-glucopyranoside 10a [55], 2,3,4,6-tetra-O-acetyl- $\alpha$-D-glucopyranosyl bromide 11a, 2,3,4,6-tetra-O-acetyl- $\alpha$-D-galactopyranosyl bromide 11b [54], 2,3,4,6-tetra-Oacetyl- $\beta$-D-glucopyranosyl azide 12a, 2,3,4,6-tetra- $O$-acetyl- $\beta$-D-galactopyranosyl azide 12b [36], 2,3,4,6-tetra-O-acetyl-N-( $\beta$-D-glucopyranosyl)chloroacetamide 13a, 2,3,4,6-tetra-O-acetyl- $N-(\beta-\mathrm{D}-$ galacto-pyranosyl)chloroacetamide 13b, 2,3,4,6-tetra- $O$-acetyl- $N$-( $\beta$-D-glucopyranosyl)azidoacetamide 14a, and 2,3,4,6-tetra-O-acetyl- $N$-( $\beta$-D-galactopyranosyl)azidoacetamide 14b [37] were prepared according to the respective published procedures. All used chemicals were purchased from Sigma-Aldrich, Fluka, Avantor, and ACROS Organics and were used without purification.

\subsection{Chemistry}

\subsubsection{Procedure for the Synthesis of Betulin Analogs}

Procedure for the Synthesis of 28-O-propargylbetulin 2 and 3,28-O,O'-di(propargyl)betulin 3

Betulin $1(0.226 \mathrm{mmol}, 100.0 \mathrm{mg})$ and sodium hydride ( $\mathrm{NaH}, 0.904 \mathrm{mmol}, 21.7 \mathrm{mg})$ were dissolved in dry THF $(1.3 \mathrm{~mL})$ followed by addition of propargyl bromide $(0.723 \mathrm{mmol}, 0.062 \mathrm{~mL})$. The heterogenous reaction mixture was left on the magnetic stirrer for $24 \mathrm{~h}$ at room temperature. The reaction progress was monitored on TLC in an eluents system DCM:AcOEt (10:1). Then, $\mathrm{NH}_{4} \mathrm{Cl}(0.411 \mathrm{mmol}, 22.0 \mathrm{mg}$, $\left.5 \mathrm{~mL} \mathrm{H}_{2} \mathrm{O}\right)$ was added, extracted with $\mathrm{Et}_{2} \mathrm{O}(5 \times 4 \mathrm{~mL})$, brine $(5 \mathrm{~mL})$ added, and dried over $\mathrm{MgSO}_{4}$. After, this was followed by filtration and evaporation in vacuo. The crude products were purified using column chromatography (DCM:AcOEt, gradient: 50:1 to 10:1).

28-O-Propargylbetulin 2 was obtained as a white solid (58.8 mg, $54 \%$ yield); m.p.: $81-85{ }^{\circ} \mathrm{C} ;[\alpha]^{25} \mathrm{D}$ $=+11.3\left(\right.$ c $\left.0.5, \mathrm{CHCl}_{3}\right)$; HRMS $\left(\mathrm{ESI}^{+}\right)$: calcd for $\mathrm{C}_{33} \mathrm{H}_{53} \mathrm{O}_{2}\left([\mathrm{M}+\mathrm{H}]^{+}\right): m / z$ 481.4046; found: $m / z$ 481.4050; ${ }^{1} \mathrm{H} \mathrm{NMR}\left(400 \mathrm{MHz}, \mathrm{CDCl}_{3}\right): \delta_{\mathrm{H}} 4.68$ (s, br, 1H, H-29a), 4.58 (s, br, 1H, H-29b), 4.18 (dd, 1H, J $2.4 \mathrm{~Hz}, J_{2}$ $\left.16.0 \mathrm{~Hz}, \mathrm{OCH}_{\mathrm{a}} \mathrm{C} \equiv\right), 4.11\left(\mathrm{dd}, 1 \mathrm{H}, J_{1} 2.4 \mathrm{~Hz}, J_{2} 16.0 \mathrm{~Hz}, \mathrm{OCH}_{\mathrm{b}} \mathrm{C} \equiv\right), 3.70(\mathrm{~d}, 1 \mathrm{H}, \mathrm{J}$ 9.2 Hz, H-28a), 3.21-3.15 (m, 2H, H-28b, H-3), 2.45-2.38 (m, 1H, H-19), 2.42 (dd t, 1H, J 2.4 Hz, इCH), 2.1-0.60 (m, 25H, CH, $\left.\mathrm{CH}_{2}\right), 1.68$ (s, 3H, H-30), 1.05, 0.97 br, 0.83, 0.76 (all s, 3H each, H-23-H-27) ppm; ${ }^{13} \mathrm{C}$ NMR $(150 \mathrm{MHz}$, $\left.\mathrm{CDCl}_{3}\right) \delta_{\mathrm{C}} 150.64,109.56,80.51,78.97,74.01,68.27,58.61,55.28,50.42,48.91,47.99,42.66,40.98,38.86$, $38.69,37.17,34.69,34.22,29.90,29.79,27.99,27.39,27.14,25.22,20.87,19.09,18.29,16.11,15.98,15.37$, 14.83 ppm (Supplementary Materials, Table S1); IR (ATR) v: 3350-3200, 2940, 2871, 1640, 1457, 1092, $882 \mathrm{~cm}^{-1}$.

3,28-O,O'-Di(propargyl)betulin 3 was obtained as a yellow resin (36.5 mg, 31\% yield); m.p.: resin; $[\alpha]^{25}{ }_{\mathrm{D}}=+31.9\left(\mathrm{c} 0.5, \mathrm{CHCl}_{3}\right)$; HRMS $\left(\mathrm{ESI}^{+}\right)$: calcd for $\mathrm{C}_{36} \mathrm{H}_{55} \mathrm{O}_{2}\left([\mathrm{M}+\mathrm{H}]^{+}\right): \mathrm{m} / z$ 519.4202; found: $m / z$ 519.4202; ${ }^{1} \mathrm{H}$ NMR $\left(600 \mathrm{MHz}, \mathrm{CDCl}_{3}\right): \delta_{\mathrm{H}} 4.68$ (d, 1H, J $\left.2.4 \mathrm{~Hz}, \mathrm{H}-29 \mathrm{a}\right), 4.58$ (dd, 1H, J1 $1.8 \mathrm{~Hz}, J_{2} 2.4 \mathrm{~Hz}$,

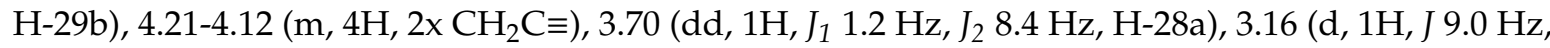
H-28b), 3.00 (dd, 1H, J1 4.2 Hz, J2 11.4 Hz, H-3), 2.44-2.39 (m, 1H, H-19), 2.41 i 2.36 (all dd t, 1H each, J $2.4 \mathrm{~Hz}$, 三CH), 2.10-0.60 (m, 24H, CH, CH $), 1.68$ (s, 3H, H-30), 1.04, 0.98, 0.97, 0.83, 0.76 (all s, 3H each, H-23-H-27) ppm; ${ }^{13} \mathrm{C}$ NMR (150 MHz, $\left.\mathrm{CDCl}_{3}\right) \delta_{\mathrm{C}} 150.64,109.56,85.86,80.96,80.50,74.01,73.41,68.25$, $58.62,56.42,55.87,50.41,48.92,48.00,47.02,42.65,41.03,38.55,37.12,34.69,34.24,29.91,29.71,27.99$, 
27.12, 25.24, 20.91, 18.25, 19.11, 16.10, 16.00, 15.99, 14.79 ppm (Supplementary Materials, Table S1); IR (ATR) v: 3314, 3261, 2952, 1610, 1453, 1377, 1085, 1068, $881 \mathrm{~cm}^{-1}$.

Procedure for the Synthesis of 28-O-(2-azidoacetyl)betulin 6

28-O-(2-Chloroacetyl)betulin $4(0.193 \mathrm{mmol}, 100.0 \mathrm{mg})$ was dissolved in DMF $(1.93 \mathrm{~mL})$ and sodium azide $(0.963 \mathrm{mmol}, 62.6 \mathrm{mg})$ was added. The heterogenous reaction mixture was stirred at $90^{\circ} \mathrm{C}$ for $3 \mathrm{~h}$. Then, $\mathrm{H}_{2} \mathrm{O}(1 \mathrm{~mL})$ and saturated $\mathrm{NaHCO}_{3}$ solution $(4 \mathrm{~mL})$ was added. It was extracted with $\mathrm{DCM}(5 \times 4 \mathrm{~mL})$ and dried over $\mathrm{MgSO}_{4}$. After that, this was followed by filtration and evaporation in vacuo. The crude product was purified using column chromatography (DCM:MeOH, gradient: 100:1 to $10: 1)$.

28-O-(2-Azidoacetyl)betulin 6 was obtained as a white solid ( $65.0 \mathrm{mg}, 64 \%$ yield); ${ }^{1} \mathrm{H} \mathrm{NMR}(600 \mathrm{MHz}$, $\left.\mathrm{CDCl}_{3}\right): \delta_{\mathrm{H}} 4.70(\mathrm{~d}, 1 \mathrm{H}, J 1.8 \mathrm{~Hz}, \mathrm{H}-29 \mathrm{a}), 4.60(\mathrm{~d}, 1 \mathrm{H}, J 1.2 \mathrm{~Hz}, \mathrm{H}-29 \mathrm{~b}), 4.41$ (dd, $1 \mathrm{H}, J_{1} 1.2 \mathrm{~Hz}, J_{2} 10.8 \mathrm{~Hz}$, H-28a), 3.99 (d, $1 \mathrm{H}, J 11.4 \mathrm{~Hz}, \mathrm{H}-28 \mathrm{~b}), 3.89$ (s, 2H, $\mathrm{CH}_{2} \mathrm{~N}_{3}$ ), 3.18 (dd, $1 \mathrm{H}, J_{1} 4.8 \mathrm{~Hz}, J_{2} 11.4 \mathrm{~Hz}, \mathrm{H}-3$ ), $2.44\left(\mathrm{td}, 1 \mathrm{H}, J_{1} 5.8 \mathrm{~Hz}, J_{2} 10.9 \mathrm{~Hz}, \mathrm{H}-19\right), 2.10-0.60$ (m, 25H, CH, CH $\mathrm{CH}_{2}, 1.68$ (s, 3H, H-30), 1.04, 0.98, 0.97, 0.83, 0.76 (all s, 3H each, H-23-H-27) ppm; ${ }^{13} \mathrm{C}$ NMR $\left(150 \mathrm{MHz}, \mathrm{CDCl}_{3}\right) \delta_{\mathrm{C}} 168.65,149.76,109.92$, $78.84,64.31,55.21,50.41,50.26,48.72,47.57,46.33,42.62,40.79,38.77,38.62,37.06,34.39,34.09,29.59$, 27.89, 27.30, 26.92, 25.09, 20.67, 19.04, 18.19, 16.00, 15.94, 15.27, 14.69 ppm (Supplementary Materials, Table S1).

Procedure for the Synthesis of 3,28-O,O'-di(2-azidoacetyl)betulin 7

3,28-O,O'-Di(2-chloroacetyl)betulin $5(0.168 \mathrm{mmol}, 100.0 \mathrm{mg})$ was dissolved in $0.71 \mathrm{~mL}$ DMF and sodium azide $(0.897 \mathrm{mmol}, 58.3 \mathrm{mg})$ was added. The heterogenous reaction mixture was stirred at $90{ }^{\circ} \mathrm{C}$ for $3 \mathrm{~h}$. Then, $\mathrm{H}_{2} \mathrm{O}$ and saturated $\mathrm{NaHCO}_{3}$ solution $(4 \mathrm{~mL})$ was added. It was extracted with $\mathrm{DCM}(4 \times 4 \mathrm{~mL})$ and dried over $\mathrm{MgSO}_{4}$. After that, this was followed by filtration and evaporation in vacuo. The crude product was purified using column chromatography (DCM:MeOH, gradient: 100:1 to $10: 1)$.

3,28-O,O'-Di(2-azidoacetyl)betulin 7 was obtained as a white solid (73.6 mg, 72\% yield); ${ }^{1} \mathrm{H}$ NMR $\left(600 \mathrm{MHz}, \mathrm{CDCl}_{3}\right): \delta_{\mathrm{H}} 4.70(\mathrm{~d}, 1 \mathrm{H}, J 1.2 \mathrm{~Hz}, \mathrm{H}-29 \mathrm{a}), 4.61-4.58(\mathrm{~m}, 2 \mathrm{H}, \mathrm{H}-29 \mathrm{~b}, \mathrm{H}-3), 4.42(\mathrm{~d}, 1 \mathrm{H}, J 11.4 \mathrm{~Hz}$, H-28a), 3.98 (d, 1H, J $10.8 \mathrm{~Hz}, \mathrm{H}-28 \mathrm{~b}$ ), 3.89 and 3.85 (all s, $2 \mathrm{H}$ each, $2 \mathrm{x} \mathrm{CH}_{2} \mathrm{~N}_{3}$ ), $2.44\left(\mathrm{td}, 1 \mathrm{H}, J_{1} 5.7 \mathrm{~Hz}\right.$, $\left.J_{2} 10.8 \mathrm{~Hz}, \mathrm{H}-19\right), 2.10-0.60$ (m, 24H, CH, CH ), 1.69 (s, 3H, H-30), 1.04, 0.98, 0.87, 0.866, 0.862 (all s, $3 \mathrm{H}$ each, H-23-H-27) ppm; ${ }^{13} \mathrm{C}$ NMR $\left(150 \mathrm{MHz}, \mathrm{CDCl}_{3}\right) \delta_{\mathrm{C}} 168.75,168.15,149.84,110.07,83.21,64.40$, 55.36, 50.67, 50.52, 50.25, 48.80, 47.69, 46.43, 42.67, 40.91, 38.34, 37.89, 37.06, 34.49, 34.08, 29.67, 27.94, 27.00, 25.06, 23.68, 20.74, 19.05, 18.15, 16.54, 16.15, 16.04, 14.75 ppm (Supplementary Materials, Table S1); IR (ATR) v: 2942, 2867, 1728, 1243, 1181, 1017, 979, $754 \mathrm{~cm}^{-1}$.

3.2.2. General Procedure for the Synthesis of Betulin Glycoconjugates 15-16 according to Strategy I (Modification C28)

To a well-stirred 28-O-propargylbetulin $\quad 2 \quad(0.208 \quad \mathrm{mmol}, \quad 100.0 \mathrm{mg})$ and 2,3,4,6-tetra-O-acetyl- $\beta$-D-galactopyranosyl or 2,3,4,6-tetra- $O$-acetyl- $\beta$-D-glucopyranosyl azide 12a-b $(0.208 \mathrm{mmol}, 77.7 \mathrm{mg})$ or $\mathbf{1 4 a}-\mathbf{b}(0.208 \mathrm{mmol}, 89.5 \mathrm{mg})$ in $i-\mathrm{PrOH}(2 \mathrm{~mL})$ were added $\mathrm{CuSO}_{4} \cdot 5 \mathrm{H}_{2} \mathrm{O}$ ( $0.125 \mathrm{mmol}, 31.2 \mathrm{mg})$ dissolved in $\mathrm{H}_{2} \mathrm{O}(1 \mathrm{~mL})$ and sodium ascorbate $(0.229 \mathrm{mmol}, 45.3 \mathrm{mg})$ dissolved in $\mathrm{H}_{2} \mathrm{O}(1 \mathrm{~mL})$ succesively. The reaction mixture was stirred under argon atmosphere for $24 \mathrm{~h}$ at room temperature. After completion of the reaction (was monitored by TLC), the reaction mixture was extracted with DCM (15a-b: $5 \times 5 \mathrm{~mL})$ or AcOEt (16a-b: $5 \times 5 \mathrm{~mL})$, then the mixture was dried over $\mathrm{MgSO}_{4}$ and was concentrated in vacuo. The crude residue was separated/purified using column chromatography (15a-b: DCM:AcOEt, gradient: 20:1 to 1:1; 16a-b: DCM:MeOH, gradient: 50:1 to 10:1).

Product $15 a\left(28-\mathrm{OCH}_{2}\right.$ TriazGlcBN) was obtained as a white solid (175.1 $\mathrm{mg}$, $99 \%$ yield); m.p.: $108-109{ }^{\circ} \mathrm{C} ;[\alpha]^{25} \mathrm{D}=-21.8\left(\mathrm{c} 0.5, \mathrm{CHCl}_{3}\right)$; HRMS $\left(\mathrm{ESI}^{+}\right)$: calcd for $\mathrm{C}_{47} \mathrm{H}_{72} \mathrm{~N}_{3} \mathrm{O}_{11}\left([\mathrm{M}+\mathrm{H}]^{+}\right): \mathrm{m} / \mathrm{z}$ 854.5167; found: $m / z$ 854.5165; ${ }^{1} \mathrm{H}$ NMR $\left(600 \mathrm{MHz}, \mathrm{CDCl}_{3}\right): \delta_{\mathrm{H}} 7.75\left(\mathrm{~s}, \mathrm{br}, 1 \mathrm{H}, \mathrm{H}-5_{\text {triaz. }}\right), 5.89(\mathrm{~d}, 1 \mathrm{H}, J$ 
$\left.9.0 \mathrm{~Hz}, \mathrm{H}-1_{\mathrm{Glc}}\right), 5.46\left(\mathrm{dd} \sim \mathrm{t}, 1 \mathrm{H}, J_{1} 9.1 \mathrm{~Hz}, J_{2} 9.5 \mathrm{~Hz}, \mathrm{H}-3_{\mathrm{Glc}}\right), 5.42\left(\mathrm{dd} \sim \mathrm{t}, 1 \mathrm{H}, J_{1} 9.0 \mathrm{~Hz}, J_{2} 9.5 \mathrm{~Hz}, \mathrm{H}-2_{\mathrm{Glc}}\right)$, $5.25\left(\mathrm{dd} \sim \mathrm{t}, 1 \mathrm{H}, J_{1} 9.1 \mathrm{~Hz}, J_{2} 10.2 \mathrm{~Hz}, \mathrm{H}-4_{\mathrm{Glc}}\right), 4.67\left(\mathrm{~d}, 1 \mathrm{H}, J 13.2 \mathrm{~Hz}, \mathrm{OCH}_{\mathrm{a}}\right), 4.66$ (s, br, 1H, H-29a), $4.60\left(\mathrm{~d}, 1 \mathrm{H}, J 12.6 \mathrm{~Hz}, \mathrm{OCH}_{\mathrm{b}}\right), 4.55\left(\mathrm{dd}, 1 \mathrm{H}, J_{1} 1.2 \mathrm{~Hz}, J_{2} 2.4 \mathrm{~Hz}, \mathrm{H}-29 \mathrm{~b}\right), 4.30$ (dd, $1 \mathrm{H}, J_{1} 5.0 \mathrm{~Hz}, J_{2}$ $\left.12.6 \mathrm{~Hz}, \mathrm{H}-6 \mathrm{a}_{\mathrm{Glc}}\right), 4.14\left(\mathrm{dd}, 1 \mathrm{H}, J_{1} 2.1 \mathrm{~Hz}, J_{2} 12.6 \mathrm{~Hz}, \mathrm{H}-6 \mathrm{~b}_{\mathrm{Glc}}\right), 4.00\left(\mathrm{ddd}, 1 \mathrm{H}, J_{1} 2.1 \mathrm{~Hz}, J_{2} 5.0 \mathrm{~Hz}, J_{3}\right.$ $\left.10.2 \mathrm{~Hz}, \mathrm{H}-5_{\mathrm{Glc}}\right), 3.63$ (d, 1H, J 8.4 Hz, H-28a), 3.19-3.17 (m, 2H, H-28a, H-3), 2.38 (td, 1H, J $5.8 \mathrm{~Hz}, J_{2}$ $11.1 \mathrm{~Hz}, \mathrm{H}-19), 2.10-0.60\left(\mathrm{~m}, 25 \mathrm{H}, \mathrm{CH}, \mathrm{CH}_{2}\right), 2.08,2.07,2.03,1.88$ (all s, $3 \mathrm{H}$ each, $\left.4 \mathrm{x} \mathrm{CH}_{3} \mathrm{CO}\right), 1.66$ (s, $3 \mathrm{H}, \mathrm{H}-30), 1.02,0.97,0.96,0.83,0.76$ (all s, $3 \mathrm{H}$ each, H-23-H-27) ppm; ${ }^{13} \mathrm{C}$ NMR $\left(150 \mathrm{MHz}, \mathrm{CDCl}_{3}\right) \delta_{\mathrm{C}}$ $170.45,169.90,169.32,168.87,150.57,146.62,120.58,109.60,85.73,78.95,75.12,72.73,70.32,68.94,67.72$, $64.95,61.58,55.31,50.42,48.85,47.88,47.26,42.68,40.92,38.88,38.73,37.51,37.17,34.77,34.26,29.91$, 29.85, 28.00, 27.42, 25.22, 20.85, 20.66, 20.53, 20.51, 20.20, 19.06, 18.32, 16.11, 16.03, 15.37, 14.79 ppm (Supplementary Materials, Table S2); IR (ATR) v: 3400-3500, 2941, 1751, 1650, 1455, 1367, 1216, 1038, $731 \mathrm{~cm}^{-1}$.

Product $15 \boldsymbol{b}$ (28-OCH $\mathrm{OCH}_{2}$ TriazGalBN) was obtained as a white solid (201.7 $\mathrm{mg}$, 97\% yield); m.p.: $117-118{ }^{\circ} \mathrm{C} ;[\alpha]^{25} \mathrm{D}=-9.4\left(\mathrm{c} 0.5, \mathrm{CHCl}_{3}\right)$; HRMS $\left(\mathrm{ESI}^{+}\right)$: calcd for $\mathrm{C}_{47} \mathrm{H}_{71} \mathrm{~N}_{3} \mathrm{O}_{11} \mathrm{Na}\left([\mathrm{M}+\mathrm{Na}]^{+}\right): \mathrm{m} / \mathrm{z}$ 876.4986; found: $m / z$ 876.4989; ${ }^{1} \mathrm{H}$ NMR $\left(600 \mathrm{MHz}, \mathrm{CDCl}_{3}\right): \delta_{\mathrm{H}} 7.80\left(\mathrm{~s}, \mathrm{br}, 1 \mathrm{H}, \mathrm{H}-5_{\text {triaz. }}\right), 5.84(\mathrm{~d}, 1 \mathrm{H}, J$ $\left.9.3 \mathrm{~Hz}, \mathrm{H}-1_{\mathrm{Gal}}\right), 5.58\left(\mathrm{dd}, 1 \mathrm{H}, J_{1} 9.3 \mathrm{~Hz}, J_{2} 10.2 \mathrm{~Hz}, \mathrm{H}-2_{\mathrm{Gal}}\right), 5.55\left(\mathrm{dd}, 1 \mathrm{H}, J_{1} 0.8 \mathrm{~Hz}, J_{2} 3.4 \mathrm{~Hz}, \mathrm{H}-4_{\mathrm{Gal}}\right.$ ), $5.25\left(\mathrm{dd}, 1 \mathrm{H}, J_{1} 3.4 \mathrm{~Hz}, J_{2} 10.2 \mathrm{~Hz}, \mathrm{H}-3_{\mathrm{Gal}}\right), 4.69-4.57$ (m, 4H, OCH $\left., \mathrm{H}-29 \mathrm{a}, \mathrm{H}-29 \mathrm{~b}\right), 4.24-4.18$ (m, 2H, H-6a $\left.\mathrm{Gal}_{1}, \mathrm{H}-5_{\mathrm{Gal}}\right), 4.13\left(\mathrm{~d}, 1 \mathrm{H}, J_{1} 6.3 \mathrm{~Hz}, J_{2} 10.9 \mathrm{~Hz}, \mathrm{H}-6 \mathrm{~b}_{\mathrm{Gal}}\right), 3.63(\mathrm{~d}, 1 \mathrm{H}, J 8.2 \mathrm{~Hz}, \mathrm{H}-28 \mathrm{a}), 3.21-3.17$ (m, 2H, H-28a, H-3), 2.40 (td, $\left.1 \mathrm{H}, J_{1} 6.0 \mathrm{~Hz}, J_{2} 11.1 \mathrm{~Hz}, \mathrm{H}-19\right), 2.30-0.60\left(\mathrm{~m}, 25 \mathrm{H}, \mathrm{CH}, \mathrm{CH}_{2}\right), 2.22,2.04,2.01$, 1.90 (all s, $3 \mathrm{H}$ each, $4 \times \mathrm{CH}_{3} \mathrm{CO}$ ), 1.66 (s, 3H, H-30), 1.02, 0.97, 0.96, 0.83, 0.76 (all s, 3H each, H-23-H-27). ppm; ${ }^{13} \mathrm{C} \mathrm{NMR}\left(150 \mathrm{MHz}, \mathrm{CDCl}_{3}\right) \delta_{\mathrm{C}} 170.28,169.95,169.80,169.04,150.61,146.46,120.76,109.60,86.27$, 78.96, 74.02, 70.89, 68.94, 67.85, 66.87, 64.91, 61.15, 55.30, 50.41, 48.84, 47.87, 47.26, 42.69, 40.93, 38.88, $38.72,37.50,37.17,34.79,34.25,29.95,29.86,28.00,27.42,27.23,25.22,20.84,20.66,20.62,20.49,20.30$, $19.06,18.33,16.11,16.00,15.37,14.80$ ppm (Supplementary Materials, Table S2); IR (ATR) v: 3600-3200, 2930, 2868, 1749, 1650, 1456, 1370, 1214, 1042, $731 \mathrm{~cm}^{-1}$.

Product 16a (28-OCH TriazCH$\left._{2}(\mathrm{CO}) \mathrm{NHGlcBN}\right)$ was obtained as a white solid (190.0 mg, 99\% yield); m.p.: $127-129{ }^{\circ} \mathrm{C} ;[\alpha]^{25} \mathrm{D}=+11.4\left(\mathrm{c} 0.5, \mathrm{CHCl}_{3}\right)$; $\mathrm{HRMS}\left(\mathrm{ESI}^{+}\right)$: calcd for $\mathrm{C}_{49} \mathrm{H}_{74} \mathrm{~N}_{4} \mathrm{O}_{12} \mathrm{Na}\left([\mathrm{M}+\mathrm{Na}]^{+}\right)$: $m / z$ 933.5201; found: $m / z$ 933.5202; ${ }^{1} \mathrm{H}$ NMR $\left(600 \mathrm{MHz}, \mathrm{CDCl}_{3}\right): \delta_{\mathrm{H}} 7.66\left(\mathrm{~s}, \mathrm{br}, 1 \mathrm{H}, \mathrm{H}-5_{\text {triaz. }}\right), 6.99(\mathrm{~d}, 1 \mathrm{H}$, $J 8.8 \mathrm{~Hz}, \mathrm{NH}), 5.29\left(\mathrm{dd} \sim \mathrm{t}, 1 \mathrm{H}, J 9.5 \mathrm{~Hz}, \mathrm{H}-1_{\mathrm{Glc}}\right), 5.21\left(\mathrm{dd}, 1 \mathrm{H}, J_{1} 8.9 \mathrm{~Hz}, J_{2} 9.4 \mathrm{~Hz}, \mathrm{H}-3_{\mathrm{Glc}}{ }^{\mathrm{a}}\right), 5.12(\mathrm{~d}, 1 \mathrm{H}$, $\left.J 16.6 \mathrm{~Hz}, \mathrm{OCH}_{\mathrm{a}}{ }^{\mathrm{b}}\right), 5.05\left(\mathrm{dd}, 1 \mathrm{H}, J_{1} 9.4 \mathrm{~Hz}, J_{2} 10.1 \mathrm{~Hz}, \mathrm{H}-4_{\mathrm{Glc}^{\mathrm{a}}}{ }^{\mathrm{a}}\right), 5.04\left(\mathrm{~d}, 1 \mathrm{H}, J 16.5 \mathrm{~Hz}, \mathrm{OCH}_{\mathrm{b}}{ }^{\mathrm{b}}\right), 4.90$ $\left(\mathrm{dd} \sim \mathrm{t}, 1 \mathrm{H}, J 9.6 \mathrm{~Hz}, \mathrm{H}-2 \mathrm{Glc}^{\mathrm{a}}\right), 4.67$ (s, br, 3H, H-29a, $\left.\mathrm{CH}_{2} \mathrm{CO}^{\mathrm{b}}\right), 4.57\left(\mathrm{dd}, 1 \mathrm{H}, J_{1} 1.4 \mathrm{~Hz}, J_{2} 2.1 \mathrm{~Hz}, \mathrm{H}-29 \mathrm{~b}\right)$, $4.28\left(\mathrm{dd}, 1 \mathrm{H}, J_{1} 4.4 \mathrm{~Hz}, J_{2} 12.5 \mathrm{~Hz}, \mathrm{H}-6 \mathrm{a}_{\mathrm{Glc}}\right), 4.09\left(\mathrm{dd}, 1 \mathrm{H}, J_{1} 2.2 \mathrm{~Hz}, J_{2} 12.5 \mathrm{~Hz}, \mathrm{H}-6 \mathrm{~b}_{\mathrm{Glc}}\right), 3.81(\mathrm{ddd}, 1 \mathrm{H}$, $\left.J_{1} 2.2 \mathrm{~Hz}, J_{2} 4.4 \mathrm{~Hz}, J_{3} 10.1 \mathrm{~Hz}, \mathrm{H}-5_{\mathrm{Glc}}\right), 3.63$ (d, 1H, J 9.1 Hz, H-28a), 3.22-2.18 (m, 2H, H-28b, H-3), 2.39 $\left(\mathrm{td}, 1 \mathrm{H}, J_{1} 5.8 \mathrm{~Hz}, J_{2} 10.8 \mathrm{~Hz}, \mathrm{H}-19\right), 2.15-0.60\left(\mathrm{~m}, 25 \mathrm{H}, \mathrm{CH}, \mathrm{CH}_{2}\right), 2.08,2.03,2.02,2.01$ (all s, $3 \mathrm{H}$ each, $4 \mathrm{x}$ $\mathrm{CH}_{3} \mathrm{CO}$ ), 1.67 (s, 3H, H-30), 0.97, 0.96, 0.956, 0.82, 0.77 (all s, 3H each, H-23-H-27) ppm; ${ }^{13} \mathrm{C}$ NMR (150 $\left.\mathrm{MHz}_{\mathrm{CDCl}}\right) \delta_{\mathrm{C}} 170.86,170.57,169.84,169.49,165.68,150.53,146.71,123.76,109.64,78.99,78.41,73.80$, $72.51,70.32,68.95,68.01,65.14,61.56,55.28,52.59,50.38,48.83,47.88,47.23,42.64,40.88,38.8638 .70$, $37.49,37.15,34.73,34.23,29.86,29.69,28.01,27.40,27.16,25.18,20.83,20.73,20.56,20.54,19.08,18.33$, 16.12, 15.93, 15.41, 14.79 ppm (Supplementary Materials, Table S2); IR (ATR) v: 3200-3400, 2937, 1749, 1650, 1450, 1367, 1223, 1037, 993, 907, 882, $753 \mathrm{~cm}^{-1}$. ${ }^{\mathbf{a}, \mathbf{b}}$ Reverse signal assignment is possible.

Product $16 \boldsymbol{b}$ (28-OCH $\mathrm{TriazCH}_{2}(\mathrm{CO}) \mathrm{NHGalBN}$ ) was obtained as a white solid (184.0 mg, $97 \%$ yield); m.p.: $117-120{ }^{\circ} \mathrm{C} ;[\alpha]^{25} \mathrm{D}=+14.3\left(\mathrm{c} 0.5, \mathrm{CHCl}_{3}\right)$; $\mathrm{HRMS}\left(\mathrm{ESI}^{+}\right)$: calcd for $\mathrm{C}_{49} \mathrm{H}_{74} \mathrm{~N}_{4} \mathrm{O}_{12} \mathrm{Na}\left([\mathrm{M}+\mathrm{Na}]^{+}\right)$: $m / z$ 933.5201; found: $m / z$ 933.5202; ${ }^{1} \mathrm{H}$ NMR $\left(600 \mathrm{MHz}, \mathrm{CDCl}_{3}\right): \delta_{\mathrm{H}} 7.66\left(\mathrm{~s}, \mathrm{br}, 1 \mathrm{H}, \mathrm{H}-5_{\text {triaz. }}\right), 6.93(\mathrm{~d}$, $1 \mathrm{H}, J 8.9 \mathrm{~Hz}, \mathrm{NH}), 5.43\left(\mathrm{dd}, 1 \mathrm{H}, J_{1} 0.9 \mathrm{~Hz}, J_{2} 3.3 \mathrm{~Hz}, \mathrm{H}-4_{\mathrm{Gal}}\right), 5.19\left(\mathrm{dd}, 1 \mathrm{H}, J_{1} 8.9 \mathrm{~Hz}, J_{2} 9.2 \mathrm{~Hz}, \mathrm{H}-1_{\mathrm{Gal}}\right)$, 5.12 and $4.99\left(\mathrm{qAB}, 2 \mathrm{H}, J 3.3 \mathrm{~Hz}, \mathrm{CH}_{2} \mathrm{CO}\right), 5.11\left(\mathrm{dd}, 1 \mathrm{H}, J_{1} 3.3 \mathrm{~Hz}, J_{2} 10.3 \mathrm{~Hz}, \mathrm{H}-3_{\mathrm{Gal}}\right), 5.06\left(\mathrm{dd}, 1 \mathrm{H}, J_{1}\right.$ $\left.9.2 \mathrm{~Hz}, J_{2} 10.3 \mathrm{~Hz}, \mathrm{H}-2_{\mathrm{Gal}}\right), 4.68$ (s, 2H, OCH $)_{2}, 4.67$ and 4.57 (s, br, 1H each, H-29a, H-29b), 4.11 (dd, $\left.1 \mathrm{H}, J_{1} 6.9 \mathrm{~Hz}, J_{2} 11.3 \mathrm{~Hz}, \mathrm{H}-6 \mathrm{a}_{\mathrm{Gal}}\right), 4.07$ (dd, $\left.1 \mathrm{H}, J_{1} 6.2 \mathrm{~Hz}, J_{2} 11.23 \mathrm{~Hz}, \mathrm{H}-6 \mathrm{~b}_{\mathrm{Gal}}\right), 4.02\left(\mathrm{~m}, 1 \mathrm{H}, \mathrm{H}-5_{\mathrm{Gal}}\right)$, 3.63 (d, 1H, J 8.9 Hz, H-28a), 3.22-3.18 (m, 2H, H-28b, H-3), 2.39 (td, 1H, J1 5.9 Hz, J2 10.8 Hz, H-19), 2.30-0.60 (m, 25H, CH, CH $)$, 2.15, 2.04, 2.03, 1.98 (all s, 3H each, 4x $\mathrm{CH}_{3} \mathrm{CO}$ ), 1.67 (s, 3H, H-30), 0.97, 0.96, 0.957, 0.82, 0.77 (all s, 3H each, H-23-H-27) ppm; ${ }^{13} \mathrm{C}$ NMR $\left(150 \mathrm{MHz}, \mathrm{CDCl}_{3}\right) \delta_{\mathrm{C}} 171.00,170.37$, 
$169.98,169.73,165.67,150.53,146.60,123.86,109.63,78.98,78.61,72.56,70.71,68.98,68.06,67.08,65.13$, $61.08,55.29,52.55,50.39,48.84,47.89,47.24,42.65,40.89,38.87,38.71,37.50,37.16,34.74,34.24,29.88$, 29.86, 28.01, 27.39, 27.17, 25.19, 20.84, 20.67, 20.64, 20.60, 20.50, 19.08, 18.33, 16.12, 15.94, 15.40, 14.79 ppm (Supplementary Materials, Table S2); IR (ATR) v: 3100-2800, 1749, 1650, 1368, 1222, 1084, 1046, $752 \mathrm{~cm}^{-1}$.

3.2.3. General Procedure for the Synthesis of Betulin Glycoconjugates 17-18 according to Strategy I (Modification C3 and C28)

To a well-stirred 3,28-O,O'-di(2-propargyl)betulin $3(0.193 \mathrm{mmol}, 100.0 \mathrm{mg})$ and per-O-acetylated glucopyranosyl or galactopyranosyl azides $\mathbf{1 2 a}-\mathbf{b}(0.385 \mathrm{mmol}, 143.9 \mathrm{mg})$ or $\mathbf{1 4 a}-\mathbf{b}(0.385 \mathrm{mmol}, 165.9$ $\mathrm{mg})$ in $i-\mathrm{PrOH}(6.6 \mathrm{~mL}), \mathrm{CuSO}_{4} \cdot 5 \mathrm{H}_{2} \mathrm{O}(0.231 \mathrm{mmol}, 57.8 \mathrm{mg})$ dissolved in $\mathrm{H}_{2} \mathrm{O}(3.3 \mathrm{~mL})$ and sodium ascorbate $(0.424 \mathrm{mmol}, 84.0 \mathrm{mg})$ dissolved in $\mathrm{H}_{2} \mathrm{O}(3.3 \mathrm{~mL})$ were added successively. The reaction mixture was stirred under argon atmosphere for $24 \mathrm{~h}$ at room temperature. After completion of the reaction (was monitored by TLC), the reaction mixture was extracted with (17a-b: DCM $5 \times 5$ mL; 18b: AcOEt $5 \times 5 \mathrm{~mL}$ ), then the mixture was dried over $\mathrm{MgSO}_{4}$ and was concentrated in vacuo. The crude residue was separated/purified using column chromatography (17a-b: DCM:AcOEt, gradient: 15:1 to 1:1; 18b: DCM:MeOH, gradient: 40:1 to 10:1).

Product $17 a\left(3,28-d i\left(\mathrm{OCH}_{2}\right.\right.$ TriazGlc)BN) was obtained as a white solid (242.0 $\mathrm{mg}$, 99\% yield); m.p.: 126-127 ${ }^{\circ} \mathrm{C} ;[\alpha]^{25}{ }_{\mathrm{D}}=-6.1\left(\mathrm{c} 0.5, \mathrm{CHCl}_{3}\right)$; HRMS $\left(\mathrm{ESI}^{+}\right)$: calcd for $\mathrm{C}_{64} \mathrm{H}_{93} \mathrm{~N}_{6} \mathrm{O}_{20}\left([\mathrm{M}+\mathrm{H}]^{+}\right): m / z$ 1265.6445; found: $m / z$ 1265.6426; ${ }^{1} \mathrm{H} \mathrm{NMR}\left(600 \mathrm{MHz}, \mathrm{CDCl}_{3}\right): \delta_{\mathrm{H}} 7.75$ and 7.74 (all s, $1 \mathrm{H}$ each, $2 \mathrm{x}$ H-5 triaz.), 5.90 and 5.89 (all d, $1 \mathrm{H}$ each, $J_{1} 9.0 \mathrm{~Hz}$ and $\left.J_{2} 9.4 \mathrm{~Hz}, 2 \times \mathrm{H}-1_{\mathrm{Glc}}\right), 5.50-5.40\left(\mathrm{~m}, 4 \mathrm{H}, 2 \times \mathrm{H}-2_{\mathrm{Glc}}\right.$, $\left.2 \mathrm{x} \mathrm{H}^{-} 3_{\mathrm{Glc}}\right)$ ), 5.24 and 5.2519 (all dd, $1 \mathrm{H}$ each, $J_{1} 9.4 \mathrm{~Hz}, J_{2} 10.1 \mathrm{~Hz}$ and $\left.J_{1} 9.2 \mathrm{~Hz}, J_{2} 10.1 \mathrm{~Hz}, 2 \mathrm{x} \mathrm{H}-4_{\mathrm{Glc}}\right)$, 4.78-4.54 (m, 3H, OCH, $\mathrm{H}-29 \mathrm{~b}), 4.32-4.28$ (m, 2H, 2x H-6a $\left.\mathrm{Glc}_{\mathrm{c}}\right), 4.36-4.13$ (m, 2H, 2x H-6b $\left.\mathrm{Glc}_{\mathrm{c}}\right), 4.03-4.00$ (m, 2H, 2x H-5 $\left.\mathrm{Glc}_{\mathrm{c}}\right), 3.62$ (d, 1H, J $\left.8.4 \mathrm{~Hz}, \mathrm{H}-28 \mathrm{a}\right), 3.18$ (d, 1H, J $\left.9.0 \mathrm{~Hz}, \mathrm{H}-28 \mathrm{~b}\right), 2.95$ (dd, 1H, J1 4.2 Hz, J2 $12.0 \mathrm{~Hz}, \mathrm{H}-3), 2.38$ (td, 1H, J $\left.5.7 \mathrm{~Hz}, J_{2} 11.0 \mathrm{~Hz}, \mathrm{H}-19\right), 2.20-0.60$ (m, 24H, CH, CH $), 2.08,2.07,2.069$, 2.031, 2.029, 1.88, 1.87 (all s, 3H each, 8x CH $\mathrm{CH}_{3} \mathrm{CO}$ ) 1.66 (s, 3H, H-30), 1.01, 0.95, 0.89, 0.84, 0.78 (all s, 3H each, H-23-H-27) ppm; ${ }^{13} \mathrm{C} \mathrm{NMR}\left(150 \mathrm{MHz} \mathrm{CDCl}_{3}\right) \delta_{\mathrm{C}} 170.46,170.44,169.91,169.89,169.32,168.86$, $168.79,150.57,147.26,146.59,120.58,120.50,109.61,86.65,85.69,85.62,75.08$ 75.04, $72.8172 .71,70.31$ $70.18,68.92,67.7167 .70,64.93,62.88,61.57,55.68,50.36,48.82,47.84,47.25,42.65,40.94,38.81,38.52$, $37.48,37.11,34.76,34.24,29.89,29.83,27.97,27.18,25.20,22.83,20.85,20.66,20.53,20.51,20.17,19.05$, 18.24, 16.25, 16.12, 16.02, 14.73 ppm (Supplementary Materials, Table S2); IR (ATR) v: 2942, 1750, 1457, $1368,1216,1091,1055,1036,913,732 \mathrm{~cm}^{-1}$.

Product $\mathbf{1 7 b}\left(3,28-d i\left(\mathrm{OCH}_{2}\right.\right.$ TriazGal)BN) was obtained as a white solid (242.0 $\mathrm{mg}$, 99\% yield); m.p.: $122-123{ }^{\circ} \mathrm{C} ;[\alpha]^{25} \mathrm{D}=+4.9\left(\mathrm{c} 0.5, \mathrm{CHCl}_{3}\right) ; \mathrm{HRMS}\left(\mathrm{ESI}{ }^{+}\right)$: calcd for $\mathrm{C}_{64} \mathrm{H}_{92} \mathrm{~N}_{6} \mathrm{O}_{20} \mathrm{Na}\left([\mathrm{M}+\mathrm{Na}]^{+}\right): m / z$ 1287.6264; found: $m / z$ 1287.6206; ${ }^{1} \mathrm{H} \mathrm{NMR} \mathrm{(600} \mathrm{MHz,} \mathrm{CDCl}_{3}$ ): $\delta_{\mathrm{H}} 7.80$ and 7.79 (all s, br, $1 \mathrm{H}$ each, $2 \mathrm{x}$ H-5 triaz.), 5.86 and 5.856 (all d, $1 \mathrm{H}$ each, $J 9.4 \mathrm{~Hz}, 2 \times \mathrm{H}-1_{\mathrm{Gal}}$ ), 5.61 and 5.58 (all dd, $1 \mathrm{H}$ each, $J_{1} 9.4 \mathrm{~Hz}, J_{2}$ $\left.10.2 \mathrm{~Hz}, 2 \times \mathrm{H}-2_{\mathrm{Gal}}\right), 5.56-5.54\left(\mathrm{~m}, 2 \mathrm{H}, 2 \mathrm{x} \mathrm{H} 4_{\mathrm{Gal}}\right), 5.25$ and 5.26 (all dd, $1 \mathrm{H}$ each, $J_{1} 5.4 \mathrm{~Hz}, J_{2} 10.2 \mathrm{~Hz}, 2 \mathrm{x}$ $\left.\mathrm{H}-3_{\mathrm{Gal}}\right), 4.78-4.56$ (m, 6H, 2x OCH $\left.\mathrm{OCH}_{2}, \mathrm{H}-29 \mathrm{a}, \mathrm{H}-29 \mathrm{~b}\right), 4.26-4.23$ (m, 2H, 2x H-5 $\left.\mathrm{Gal}\right), 4.22-4.10$ (m, 4H, 2x H-6a $\left.\mathrm{Gal}_{1}, 2 \mathrm{x} \mathrm{H}-6 \mathrm{~b}_{\mathrm{Gal}}\right), 3.62(\mathrm{~d}, 1 \mathrm{H}, J 8.8 \mathrm{~Hz}, \mathrm{H}-28 \mathrm{a}), 3.20$ (d, 1H, J 9.1 Hz, H-28b), 2.97 (dd, 1H, J1 4.3 Hz, $\left.J_{2} 11.7 \mathrm{~Hz}, \mathrm{H}-3\right), 2.40$ (td, 1H, J $\left.5.7 \mathrm{~Hz}, J_{2} 11.1 \mathrm{~Hz}, \mathrm{H}-19\right), 2.23,2.22,2.044,2.04,2.013,2.01,1.90,1.88$ (all s, 3H each, 8x CH${ }_{3} \mathrm{CO}$ ), 2.30-0.60 (m, 24H, CH, $\mathrm{CH}_{2}$ ), 1.67 (s, 3H, H-30), 1.01, 0.95, 0.90, 0.84, 0.78 (all s, $3 \mathrm{H}$ each, $\mathrm{H}-23-\mathrm{H}-27) \mathrm{ppm} ;{ }^{13} \mathrm{C} \mathrm{NMR}\left(150 \mathrm{MHz}, \mathrm{CDCl}_{3}\right) \delta_{\mathrm{C}} 170.31,170.28,169.95,169.79,169.03,168.93$, $150.59,147.06,146.42,120.77,120.66,109.62,86.63,86.22,86.17,73.98,70.94,70.86,68.91,67.86,67.74$, $66.91,64.88,61.18,55.68,52.88,50.36,48.83,47.86,47.25,42.66,40.95,38.82,38.53,37.48,37.12,34.78$, $34.24,29.94,29.84,27.96,27.20,22.87,25.20,20.86,20.66,20.63,20.49,20.29,20.27,19.05,18.26,16.26$, 16.13, 16.00, 14.74 ppm (Supplementary Materials, Table S2); IR (ATR) v: 2942, 1748, 1457, 1368, 1213, $1089,1043,921,730 \mathrm{~cm}^{-1}$.

Product $18 \boldsymbol{b}\left(3,28-d i\left(\mathrm{OCH}_{2}\right.\right.$ Triaz $\left.\left.\mathrm{CH}_{2}(\mathrm{CO}) \mathrm{NHGal}\right) \mathrm{BN}\right)$ was obtained as a white solid $(216.9 \mathrm{mg}, 82 \%$ yield); m.p.: $142-145^{\circ} \mathrm{C} ;[\alpha]^{25} \mathrm{D}=+4.9\left(\right.$ c $\left.0.5, \mathrm{CHCl}_{3}\right)$; $\mathrm{HRMS}\left(\mathrm{ESI}^{+}\right)$: calcd for $\mathrm{C}_{68} \mathrm{H}_{99} \mathrm{~N}_{8} \mathrm{O}_{22}\left(\left[\mathrm{M}_{+}+\right.\right.$ $\left.\mathrm{H}]^{+}\right): m / z$ 1379.6900; found: $m / z$ 1379.6533; ${ }^{1} \mathrm{H}$ NMR $\left(600 \mathrm{MHz}, \mathrm{CDCl}_{3}\right): \delta_{\mathrm{H}} 7.66$ and $7.64($ all s, $1 \mathrm{H}$ 
each, 2x H-5 $\left.5_{\text {triaz. }}\right), 6.86$ and 6.85 (all d, $1 \mathrm{H}$ each, $\left.J 8.8 \mathrm{~Hz}, 2 \times \mathrm{NH}\right), 5.45-5.40\left(\mathrm{~m}, 2 \mathrm{H}, 2 \times \mathrm{H}-4_{\text {Gal }}\right), 5.22-5.18$ (m, 2H, $2 x_{\text {H-1 }}$ Gal $), 5.14-4.98$ (m, 8H, $2 x_{\text {H-2 }}$ Gal $\left., 2 x_{\text {H-3 }}{ }_{\mathrm{Gal}}, 2 \mathrm{CH}_{2}\right), 4.84-4.57$ (m, 6H, H-29a, H-29b,

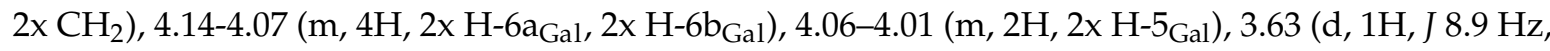
H-28a), 3.22 (d, 1H, J $9.0 \mathrm{~Hz}, \mathrm{H}-28 \mathrm{~b}), 2.97$ (dd, 1H, J $\left.1.2 \mathrm{~Hz}, J_{2} 11.7 \mathrm{~Hz}, \mathrm{H}-3\right), 2.39$ (td, 1H, J $5.9 \mathrm{~Hz}, J_{2}$ $10.6 \mathrm{~Hz}, \mathrm{H}-19), 2.30-0.60$ (m, 24H, CH, $\left.\mathrm{CH}_{2}\right), 2.15,2.14,2.04,2.03,2.02,1.98,1.977,1.96$ (all s, 3H each, 8x $\mathrm{CH}_{3} \mathrm{CO}$ ), 1.67 (s, 3H, H-30), 0.96, 0.95, 0.92, 0.83, 0.77 (all s, 3H each, H-23-H-27) ppm; ${ }^{13} \mathrm{C}$ NMR $\left(150 \mathrm{MHz}, \mathrm{CDCl}_{3}\right) \delta_{\mathrm{C}} 171.03,170.92,170.34,169.98,169.71,165.68,165.55,150.54,147.49,146.77,123.75$, $123.61,109.65,86.89,78.75,78.72,72.59,72.57,70.67,70.64,69.01,68.06,68.00,67.06,65.21,63.20,61.11$, 61.00, 55.69, 52.71, 52.65, 50.36, 48.85, 47.90, 47.25, 42.65, 40.93, 38.85, 38.52, 37.50, 37.14, 34.75, 34.24, $29.88,29.69,28.10,27.17,25.20,22.86,20.87,20.67,20.62,20.60,20.59,20.50,19.09,18.26,16.30,16.15$, 15.96, 14.76, ppm (Supplementary Materials, Table S2); IR (ATR) v: 2950, 1748, 1620, 1510, 1450, 1368, $1218,1084,1045,970,890,720 \mathrm{~cm}^{-1}$.

3.2.4. Procedure for the Synthesis of Betulin Glycoconjugates 19a according to Strategy II (Modification C28)

To a well-stirred 28-O-(2-azidoacetyl)betulin $6(0.190 \mathrm{mmol}, 100.0 \mathrm{mg})$ and per-O-acetylated glucopyranosyl propargyl 10a $(0.190 \mathrm{mmol}, 73.5 \mathrm{mg})$ in $i-\mathrm{PrOH}(2 \mathrm{~mL})$ and THF $(1 \mathrm{~mL}), \mathrm{CuSO}_{4} \cdot 5 \mathrm{H}_{2} \mathrm{O}$ $(0.114 \mathrm{mmol}, 22.6 \mathrm{mg})$ dissolved in $\mathrm{H}_{2} \mathrm{O}(1 \mathrm{~mL})$ and sodium ascorbate $(0.209 \mathrm{mmol}, 52.2 \mathrm{mg})$ dissolved in $\mathrm{H}_{2} \mathrm{O}(1 \mathrm{~mL})$ were added successively. The reaction mixture was stirred under argon atmosphere for $24 \mathrm{~h}$ at room temperature. After completion of the reaction (was monitored by TLC), the reaction mixture was extracted with DCM $(5 \times 5 \mathrm{~mL})$, then the mixture was dried over $\mathrm{MgSO}_{4}$ and was concentrated in vacuo. The crude residue was separated/purified using column chromatography (DCM:MeOH, gradient: 50:1 to 10:1).

Product $19 \boldsymbol{a}\left(28-\mathrm{O}(\mathrm{CO}) \mathrm{CH}_{2}\right.$ Triaz $\left.\mathrm{CH}_{2} \mathrm{OGlcBN}\right)$ was obtained as a white solid (168.3 $\mathrm{mg}, 97 \%$ yield); m.p.: 99-101 ${ }^{\circ} \mathrm{C} ;[\alpha]^{25} \mathrm{D}=-15.6\left(\mathrm{c} 0.5, \mathrm{CHCl}_{3}\right)$; HRMS (ESI+): calcd for $\mathrm{C}_{49} \mathrm{H}_{73} \mathrm{~N}_{3} \mathrm{O}_{13} \mathrm{Na}\left([\mathrm{M}+\mathrm{Na}]^{+}\right)$: m/z 934.5041; found: $\mathrm{m} / \mathrm{z} 934.5045 ;{ }^{1} \mathrm{H}$ NMR $\left(600 \mathrm{MHz}, \mathrm{CDCl}_{3}\right): \delta_{\mathrm{H}} 7.69\left(\mathrm{~s}, \mathrm{br}, 1 \mathrm{H}, \mathrm{H}-5_{\text {triaz }}\right), 5.22-5.17$ $\left(\mathrm{m}, 2 \mathrm{H}, \mathrm{H}-1_{\mathrm{Glc}}, \mathrm{H}-3_{\mathrm{Glc}}\right), 5.10\left(\mathrm{dd} \sim \mathrm{t}, 1 \mathrm{H}, J_{1} 9.6 \mathrm{~Hz}, J_{2} 9.8 \mathrm{~Hz}, \mathrm{H}-2_{\mathrm{Glc}}\right), 5.02\left(\mathrm{ddt}, 1 \mathrm{H}, J_{1} 8.0 \mathrm{~Hz}, J_{2} 9.5 \mathrm{~Hz}\right.$, $\mathrm{H}-4 \mathrm{Glc}$ ), 4.97 and 4.86 (qAB, 2H, $\mathrm{CH}_{2}$ ), 4.68 (s, br, 2H, $\mathrm{CH}_{2}$ ), 4.68 and 4.60 (all s, br, 1H each, H-29a, $\mathrm{H}-29 \mathrm{~b}), 4.43(\mathrm{~d}, 1 \mathrm{H}, J 10.9 \mathrm{~Hz}, \mathrm{H}-28 \mathrm{a}), 4.26$ (dd, $\left.1 \mathrm{H}, J_{1} 4.7 \mathrm{~Hz}, J_{2} 12.3 \mathrm{~Hz}, \mathrm{H}-6 \mathrm{a}_{\mathrm{Glc}}\right), 4.17$ (dd, $1 \mathrm{H}, J_{1} 2.1 \mathrm{~Hz}$, $\left.J_{2} 12.3 \mathrm{~Hz}, \mathrm{H}-6 \mathrm{~b}_{\mathrm{Glc}}\right), 3.97$ (d, 1H, J $\left.11.0 \mathrm{~Hz}, \mathrm{H}-28 \mathrm{~b}\right), 3.73$ (ddd, 1H, J $2.1 \mathrm{~Hz}, J_{2} 4.7 \mathrm{~Hz}, J_{3} 9.5 \mathrm{~Hz}, \mathrm{H}-5_{\mathrm{Glc}}$ ), $3.18\left(\mathrm{dd}, 1 \mathrm{H}, J_{1} 4.7 \mathrm{~Hz}, J_{2} 11.5 \mathrm{~Hz}, \mathrm{H}-3\right), 2.41$ (td, $\left.1 \mathrm{H}, J_{1} 5.7 \mathrm{~Hz}, J_{2} 10.7 \mathrm{~Hz}, \mathrm{H}-19\right), 2.20-0.60$ (m, 25H, CH, $\mathrm{CH}_{2}$ ), 2.10, 2.03, 2.004, 2.00 (all s, 3H each, 4x $\mathrm{CH}_{3} \mathrm{CO}$ ), 1.68 (s, 3H, H-30), 1.01, 0.98, 0.97, 0.82, 0.76 (all s, 3H each, H-23-H-27) ppm; ${ }^{13} \mathrm{C}$ NMR $\left(150 \mathrm{MHz}, \mathrm{CDCl}_{3}\right) \delta_{\mathrm{C}} 170.65,170.18,169.45,169.42,166.55$, $149.73,124.28,110.10,78.94,72.79,71.94,71.21,68.36,61.80,50.86,64.96,62.93,55.29,50.85,50.33,48.80$, $47.64,46.45,42.71,40.88,38.87,38.71,37.68,37.15,34.39,34.18,29.60,29.44,27.99,27.01,27.39,25.16$, $20.78,20.74,20.67,20.60,19.11,18.28,16.10,16.01,15.36,14.78$ ppm (Supplementary Materials, Table S2); IR (ATR) v: 3400-3200, 2942, 1747, 1640, 1456, 1366, 1218, 1037, 982, 883, $769 \mathrm{~cm}^{-1}$.

3.2.5. Procedure for the Synthesis of Betulin Glycoconjugates 20a according to Strategy II (Modification C3 and C28)

To a well-stirred 3,28-O,O'-di(2-azidoacetyl)betulin $7(0.164 \mathrm{mmol}, 100.0 \mathrm{mg})$ and per-O-acetylated glucopyranosyl propargyl 10a $(0.329 \mathrm{mmol}, 126.9 \mathrm{mg})$ in $i$-PrOH $(4.2 \mathrm{~mL})$ and THF $(1.8 \mathrm{~mL})$, $\mathrm{CuSO}_{4} \cdot 5 \mathrm{H}_{2} \mathrm{O}(0.181 \mathrm{mmol}, 45.1 \mathrm{mg})$ dissolved in $\mathrm{H}_{2} \mathrm{O}(2.1 \mathrm{~mL})$ and sodium ascorbate $(0.099 \mathrm{mmol}$, $19.5 \mathrm{mg}$ ) dissolved in $\mathrm{H}_{2} \mathrm{O}(2.1 \mathrm{~mL})$ were added successively. The reaction mixture was stirred under argon atmosphere for $24 \mathrm{~h}$ at room temperature. After completion of the reaction (was monitored by TLC), the reaction mixture was extracted with $\mathrm{DCM}(5 \times 5 \mathrm{~mL})$, then the mixture was dried over $\mathrm{MgSO} 4$ and was concentrated in vacuo. The crude residue was separated/purified using column chromatography (DCM:MeOH, gradient: 30:1 to 10:1).

Product 20a $\left(3,28-d i\left(\mathrm{O}(\mathrm{CO}) \mathrm{CH}_{2}\right.\right.$ Triaz $\left.\left.\mathrm{CH}_{2} \mathrm{OGlc}\right) \mathrm{BN}\right)$ was obtained as a white solid $(198.0 \mathrm{mg}, 87 \%$ yield); m.p.: $109-112{ }^{\circ} \mathrm{C}$; $[\alpha]^{25} \mathrm{D}=-19.0\left(\mathrm{c} 0.5, \mathrm{CHCl}_{3}\right)$; HRMS (ESI+): calcd for $\mathrm{C}_{68} \mathrm{H}_{97} \mathrm{~N}_{6} \mathrm{O}_{24}([\mathrm{M}+$ 
$\left.\mathrm{H}]^{+}\right): \mathrm{m} / \mathrm{z}$ 1381.6554; found: $\mathrm{m} / \mathrm{z} 1381.6218 ;{ }^{1} \mathrm{H}$ NMR $\left(600 \mathrm{MHz}, \mathrm{CDCl}_{3}\right): \delta_{\mathrm{H}} 7.68$ and $7.66($ all s, $1 \mathrm{H}$ each, $2 x_{\text {H- }} 5_{\text {triaz }}$ ), 5.23-5.13 (m, 4H, 2x (H-1 Glc $\left.\left.\mathrm{H}-3_{\mathrm{Glc}}\right)\right)$, 5.12-5.06 (m, 2H, 2x H-2 $\left.\mathrm{Glc}\right), 5.05-4.99(\mathrm{~m}, 2 \mathrm{H}$, $\left.2 \mathrm{x} \mathrm{H}^{-} \mathrm{Glc}_{\mathrm{Gl}}\right), 4.99-4.83\left(\mathrm{~m}, 4 \mathrm{H}, 2 \mathrm{CH}_{2}\right), 4.69-4.66\left(\mathrm{~m}, 5 \mathrm{H}, \mathrm{H}-29 \mathrm{a}, 2 \mathrm{C} \mathrm{CH}_{2}\right), 4.60$ (s, br, 1H, H-29b), 4.43 (d, $1 \mathrm{H}, \mathrm{J} 10.6 \mathrm{~Hz}, \mathrm{H}-28 \mathrm{a}$ ), 4.26 and 4.27 (all dd, $1 \mathrm{H}$ each, $J_{1} 1.0 \mathrm{~Hz}, J_{2} 12.4 \mathrm{~Hz}, 2 \mathrm{x} \mathrm{H}-6 \mathrm{a}_{\mathrm{Glc}}$ ), 4.19-4.14 (m, $\left.2 \mathrm{H}, 2 \times \mathrm{H}-6 \mathrm{~b}_{\mathrm{Glc}}\right), 3.96$ (d, 1H, J $\left.11.0 \mathrm{~Hz}, \mathrm{H}-28 \mathrm{~b}\right), 3.75-3.70$ (m, 2H, 2x H-5 ${ }_{\mathrm{Glc}}$ ), 4.56 (dd, $1 \mathrm{H}, J_{1} 5.2 \mathrm{~Hz}, J_{2}$ $10.1 \mathrm{~Hz}, \mathrm{H}-3), 2.41$ (td, 1H, J $\left.5.7 \mathrm{~Hz}, J_{2} 10.7 \mathrm{~Hz}, \mathrm{H}-19\right), 2.20-0.60$ (m, 24H, CH, $\left.\mathrm{CH}_{2}\right), 2.093,2.09,2.028$, 2.025, 2.03, 2.00, 1.998, 1.994 (all s, $3 \mathrm{H}$ each, $8 \mathrm{x} \mathrm{CH}_{3} \mathrm{CO}$ ), 1.68 (s, 3H, H-30), 1.01, 0.98, 0.97, 0.84, 0.77 (all s, 3H each, H-23-H-27) ppm; ${ }^{13} \mathrm{C}$ NMR $\left(150 \mathrm{MHz}, \mathrm{CDCl}_{3}\right) \delta_{\mathrm{C}} 170.64,170.16,169.43,166.56,165.90$, $160.42,149.68,144.65,144.55,124.25,124.24,110.16,83.86,68.37,72.80,71.94,71.22,68.37,62.94,61.81$, 61.80, 55.30, 51.05, 50.83, 50.21, 48.77, 47.65, 46.45, 42.73, 40.89, 38.27, 37.90, 37.65, 37.03, 34.38, 34.05, $29.57,29.43,28.01,27.00,25.08,23.61,21.96,20.77,20.66,20.65,20.60,19.10,18.11,16.39,16.12,16.00$, 14.75 ppm (Supplementary Materials, Table S2); IR (ATR) v: 2930, 1744, 1620, 1367, 1216, 1037, 979, 880, $752 \mathrm{~cm}^{-1}$.

3.2.6. Procedure for the Synthesis of 3,28-O,O'-di(2-(4-(hydroxymethyl-1H-1,2,3-triazol-1yl)acetyl)betulin 21

To a well-stirred 3,28-O,O'-di(2-azidoacetyl)betulin $7(0.663 \mathrm{mmol}, 403.6 \mathrm{mg})$ in $i$-PrOH $(7.6 \mathrm{~mL})$ and THF $(4.8 \mathrm{~mL})$, propargyl alcohol $(1.989 \mathrm{mmol}, 111.5 \mathrm{mg}, 0.116 \mathrm{~mL})$ and $\mathrm{CuSO}_{4} \cdot 5 \mathrm{H}_{2} \mathrm{O}(0.796 \mathrm{mmol}$, $198.6 \mathrm{mg}$ ) dissolved in $\mathrm{H}_{2} \mathrm{O}(2.7 \mathrm{~mL})$ and sodium ascorbate $(1.458 \mathrm{mmol}, 288.9 \mathrm{mg})$ dissolved in $\mathrm{H}_{2} \mathrm{O}$ $(2.7 \mathrm{~mL})$ were added successively. The reaction mixture was stirred under argon atmosphere for $24 \mathrm{~h}$ at room temperature. After completion of the reaction (was monitored by TLC), the reaction mixture was extracted with DCM $(9 \times 30 \mathrm{~mL})$, then mixture was dried over $\mathrm{MgSO}_{4}$ and was concentrated in vacuo. The crude residue was separated/purified using column chromatography (DCM:MeOH, gradient: 20:1 to $5: 1)$.

Product $21\left(3,28-d i\left(\mathrm{O}(\mathrm{CO}) \mathrm{CH}_{2}\right.\right.$ Triaz $\left.\left.\mathrm{CH}_{2} \mathrm{OH}\right) \mathrm{BN}\right)$ was obtained as a white solid $(367.2 \mathrm{mg}, 77 \%$ yield); m.p.: $105-108{ }^{\circ} \mathrm{C}$; $[\alpha]^{25} \mathrm{D}=+4.7\left(\right.$ c $\left.0.5, \mathrm{CHCl}_{3}\right)$; $\mathrm{HRMS}\left(\mathrm{ESI}^{+}\right)$: calcd for $\mathrm{C}_{40} \mathrm{H}_{61} \mathrm{~N}_{6} \mathrm{O}_{6}([\mathrm{M}+$ $\left.\mathrm{H}]^{+}\right): m / z ~ 721.4653$; found: $m / z 721.4650 ;{ }^{1} \mathrm{H} \mathrm{NMR}\left(600 \mathrm{MHz}, \mathrm{CDCl}_{3}\right): \delta_{\mathrm{H}} 7.68$ and 7.66 (all s, $1 \mathrm{H}$ each, 2x H-5 triaz. $), 5.19$ (d, 2H, J $\left.1.0 \mathrm{~Hz}, \mathrm{O}(\mathrm{CO}) \mathrm{CH}_{2}\right), 5.15$ (d, 2H, J $\left.0.6 \mathrm{~Hz}, \mathrm{O}(\mathrm{CO}) \mathrm{CH}_{2}\right), 4.82(\mathrm{br} \mathrm{s}, 4 \mathrm{H}, 2 \mathrm{x}$ $\left.\mathrm{C}_{2} \mathrm{OH}\right), 4.69(\mathrm{~d}, 1 \mathrm{H}, J 1.6 \mathrm{~Hz}, \mathrm{H}-29 \mathrm{a}), 4.60(\mathrm{~s}, 1 \mathrm{H}, \mathrm{H}-29 \mathrm{~b}), 4.57-4.54(\mathrm{~m}, 1 \mathrm{H}, \mathrm{H}-3), 4.42(\mathrm{~d}, 1 \mathrm{H}, J 10.9 \mathrm{~Hz}$, $\mathrm{H}-28 \mathrm{a}), 3.96$ (d, 1H, J $10.9 \mathrm{~Hz}, \mathrm{H}-28 \mathrm{~b}), 2.41$ (m, 3H, H-19, 2x CH $\left.\mathrm{CH}_{2} \mathrm{OH}\right), 2.10-0.60$ (m, 24H, CH, $\left.\mathrm{CH}_{2}\right)$, 1.67 (s, 3H, H-30), 1.00, 0.96, 0.83, 0.828, 0.75 (all s, 3H each, H-23-H-27) ppm; ${ }^{13} \mathrm{C}$ NMR (150 MHz, $\left.\mathrm{CDCl}_{3}\right) \delta_{\mathrm{C}} 165.97,165.61,149.96,149.66,148.09,123.08$ 110.12, 83.85, 64.92, 56.50; 55.28, 55.23, 51.08; $50.86,50.20,48.75,47.65,46.43,42.71,40.88,38.26,37.88,37.64,37.02,34.37,34.04,29.56,29.43,28.00$, $26.98,25.07,23.58,20.73,19.09,18.10,16.36,16.11,16.00,14.75$ ppm (Supplementary Materials, Table S3); IR (ATR) v: 3500-300, 2927, 2871, 1743, 1456, 1376, 1266, 1219, 1040, 1006, 977, 882, $805 \mathrm{~cm}^{-1}$.

\subsubsection{Procedure for the Deprotection of Betulin Glycoconjugates 15-17}

Glycoconjugates 15-17 (1.0 mmol) were dissolved in $\mathrm{MeOH}(\mathbf{1 5 a}-\mathbf{b}: 16 \mathrm{~mL}, \mathbf{1 6} \mathbf{a}-\mathbf{b}$ : $35 \mathrm{~mL}, \mathbf{1 7 a}-\mathbf{b}$ : $30 \mathrm{~mL}$ ). Then, $1 \mathrm{M}$ solution of $\mathrm{MeONa}$ in $\mathrm{MeOH}$ (15a-b: $0.2 \mathrm{mmol}, 0.2 \mathrm{~mL}, \mathbf{1 6 a}-\mathbf{b}: 0.4 \mathrm{mmol}, 0.4 \mathrm{~mL}$, 17a-b: $0.15 \mathrm{mmol}, 0.15 \mathrm{~mL}$ ) was added. Reaction was carried out for $120 \mathrm{~min}$ at room temperature. The reaction progress was monitored on TLC. After the reaction was complete, the mixture was neutralized with Amberlyst-15, filtered, and the filtrate was evaporated in vacuo. The crude products were crystallized from methanol.

Product $22 a\left(28-\mathrm{OCH}_{2}\right.$ TriazGlcBN) was obtained as a white solid (69.9 $\mathrm{mg}$, $87 \%$ yield); m.p.: 174-175 ${ }^{\circ} \mathrm{C} ;[\alpha]^{25} \mathrm{D}=+4.1(\mathrm{c} 0.5, \mathrm{MeOH})$; HRMS $\left(\mathrm{ESI}^{+}\right)$: calcd for $\mathrm{C}_{39} \mathrm{H}_{63} \mathrm{~N}_{3} \mathrm{O}_{7} \mathrm{Na}\left([\mathrm{M}+\mathrm{Na}]^{+}\right): \mathrm{m} / \mathrm{z}$ 708.4564; found: $m / z$ 708.4555; ${ }^{1} \mathrm{H}$ NMR $(400 \mathrm{MHz}, \mathrm{MeOD}): \delta_{\mathrm{H}} 8.19$ (s, br, $\left.1 \mathrm{H}, \mathrm{H}-5_{\text {triaz. }}\right), 5.62(\mathrm{~d}, 1 \mathrm{H}, J 9.2$ $\left.\mathrm{Hz}, \mathrm{H}-1_{\mathrm{Glc}}\right), 4.68-4.55$ (m, 4H, H-29a, H-29b, $\left.\mathrm{OCH}_{2}\right), 3.91-3.86$ (m, 2H, H-6a $\left.\mathrm{Glc}_{\mathrm{c}}, \mathrm{H}-5_{\mathrm{Glc}}\right), 3.73\left(\mathrm{dd}, 1 \mathrm{H}, J_{1}\right.$ $\left.5.2 \mathrm{~Hz}, J_{2} 12.1 \mathrm{~Hz}, \mathrm{H}-6 \mathrm{~b}_{\mathrm{Glc}}\right), 3.65$ (d, $\left.1 \mathrm{H}, J 8.9 \mathrm{~Hz}, \mathrm{H}-28 \mathrm{a}\right), 3.61-3.49\left(\mathrm{~m}, 3 \mathrm{H}, \mathrm{H}-4_{\mathrm{Glc}}, \mathrm{H}-3_{\mathrm{Glc}}, \mathrm{H}-2_{\mathrm{Glc}}\right), 3.23$ $(\mathrm{d}, 1 \mathrm{H}, J 9.0 \mathrm{~Hz}, \mathrm{H}-28 \mathrm{~b}), 3.12\left(\mathrm{dd}, 1 \mathrm{H}, J_{1} 4.9 \mathrm{~Hz}, J_{2} 11.2 \mathrm{~Hz}, \mathrm{H}-3\right), 2.43\left(\mathrm{td}, 1 \mathrm{H}, J_{1} 5.2 \mathrm{~Hz}, J_{2} 10.9 \mathrm{~Hz}, \mathrm{H}-19\right)$, 2.05-0.60 (m, 25H, CH, CH $\left.{ }_{2}\right), 1.67$ (s, 3H, H-30), 1.00, 0.98, 0.95, 0.86, 0.76 (all s, 3H each, H-23-H-27) 
ppm; ${ }^{13} \mathrm{C}$ NMR $(150 \mathrm{MHz}, \mathrm{MeOD}) \delta_{\mathrm{C}} 151.86,146.36,124.41,110.25,89.70,81.18,79.75,78.60,74.10$, $71.00,69.88,65.31,62.47,56.90,51.94,50.24,43.82,42.21,40.14,38.99,38.35,35.83,35.53,31.05,30.75$, 28.68, 28.39, 28.12, 26.71, 22.06, 19.52, 18.40, 16.76, 16.68, 16.15, 15.33 ppm (Supplementary Materials, Table S3); IR (ATR) v: 3600-3100, 2941, 2871, 1620, 1450, 1390, 1100, 1043, 1013, $880 \mathrm{~cm}^{-1}$.

Product $22 \boldsymbol{b}$ (28-OCH $\mathrm{CH}_{2}$ TriazGalBN) was obtained as a white solid (79.5 $\mathrm{mg}, 99 \%$ yield); m.p.: $218-220{ }^{\circ} \mathrm{C} ;[\alpha]^{25} \mathrm{D}=+9.1(\mathrm{c} 0.5, \mathrm{MeOH})$; HRMS $\left(\mathrm{ESI}{ }^{+}\right)$: calcd for $\mathrm{C}_{39} \mathrm{H}_{63} \mathrm{~N}_{3} \mathrm{O}_{7} \mathrm{Na}\left([\mathrm{M}+\mathrm{Na}]^{+}\right): m / z$ 708.4564; found: $m / z$ 708.4553; ${ }^{1} \mathrm{H}$ NMR (400 MHz, MeOD): $\delta_{\mathrm{H}} 8.21$ (s, br, $\left.1 \mathrm{H}, \mathrm{H}-5_{\text {triaz. }}\right), 5.57$ (d, $1 \mathrm{H}$, J $\left.9.2 \mathrm{~Hz}, \mathrm{H}-1_{\mathrm{Glc}}\right), 4.68-4.56$ (m, 4H, OCH $\left., \mathrm{H}-29 \mathrm{a}, \mathrm{H}-29 \mathrm{~b}\right), 4.15$ (dd t, 1H, J $\left.9.3 \mathrm{~Hz}, \mathrm{H}-2_{\mathrm{Gal}}\right), 4.00$ (dd, $\left.1 \mathrm{H}, J_{1} 0.9 \mathrm{~Hz}, J_{2} 3.3 \mathrm{~Hz}, \mathrm{H}-4_{\mathrm{Gal}}\right), 3.85-3.69$ (m, 3H, 2H-6 Gal, $\left.\mathrm{H}-5_{\mathrm{Gal}}\right), 3.70$ (dd, 1H, J1 3.3 Hz, J2 $9.5 \mathrm{~Hz}$, H-3 $\left.{ }_{\text {Gal }}\right), 3.64$ (d, 1H, J $\left.8.6 \mathrm{~Hz}, \mathrm{H}-28 \mathrm{a}\right), 3.23$ (d, 1H, J $\left.8.8 \mathrm{~Hz}, \mathrm{H}-28 \mathrm{~b}\right), 3.12$ (dd, 1H, J $5.0 \mathrm{~Hz}, J_{2} 11.1 \mathrm{~Hz}$, H-3), 2.43 (td, 1H, J 5.9 Hz, J2 10.9 Hz, H-19), 2.01-0.60 (m, 25H, CH, CH $), 1.67$ (s, 3H, H-30), 0.99, 0.98, 0.95, 0.86, 0.76 (all s, 3H each, H-23-H-27) ppm; ${ }^{13} \mathrm{C}$ NMR (150 MHz, MeOD) $\delta_{\mathrm{C}} 151.87,146.54,123.87$, $110.28,90.28,79.90,79.71,75.40,71.50,70.32,69.67,65.33,62.30,56.86,51.90,50.17,43.79,42.15,39.99$, 40.09 , 38.95, 38.32, 35.82, 35.46, 30.99, 30.79, 28.65, 28.34, 28.09, 26.64, 22.02, 19.41, 19.50, 16.76, 16.62, 16.16, 15.28 ppm (Supplementary Materials, Table S3); IR (ATR) v: 3600-3100, 2932, 2869, 1630, 1456, $1374,1093,1044,880 \mathrm{~cm}^{-1}$.

Product $23 \boldsymbol{b}$ (28-OCH $\mathrm{OCH}_{2}$ Triaz $\left.\mathrm{CH}_{2}(\mathrm{CO}) \mathrm{NHGalBN}\right)$ was obtained as a white solid (78.3 $\mathrm{mg}, 96 \%$ yield); m.p.: $187-190{ }^{\circ} \mathrm{C} ;[\alpha]^{25} \mathrm{D}=+6.9\left(\mathrm{c} 0.5, \mathrm{CHCl}_{3}\right)$; $\mathrm{HRMS}\left(\mathrm{ESI}^{+}\right)$: calcd for $\mathrm{C}_{41} \mathrm{H}_{67} \mathrm{~N}_{4} \mathrm{O}_{8}\left([\mathrm{M}+\mathrm{H}]^{+}\right): m / z$ 743.4959; found: $m / z$ 743.4962; ${ }^{1} \mathrm{H}$ NMR (400 MHz, MeOD): 7.96 (s, br, 1H, H-5 triaz.), 7.46 (s, 1H, NH), $5.22\left(\mathrm{q}, 2 \mathrm{H}, J 16.4 \mathrm{~Hz}, \mathrm{CH}_{2} \mathrm{~N}\right), 4.90$ (d, 1H, J $\left.8.8 \mathrm{~Hz}, \mathrm{H}-1_{\mathrm{Gal}}\right), 4.68$ and 4.57 (s, br, 1H, H-29a, H-29b), 4.65 (s, 2H, OCH 2$), 3.94$ (d, 1H, J 2.8 Hz, H-4 $\left.\mathrm{Gal}_{2}\right), 3.83-3.54\left(\mathrm{~m}, 5 \mathrm{H}, \mathrm{H}-28 \mathrm{a}, \mathrm{H}-2_{\mathrm{Gal}}, \mathrm{H}-3_{\mathrm{Gal}}, \mathrm{H}-5_{\mathrm{Gal}}\right.$, H-6a $\left.\mathrm{Gal}_{1} \mathrm{H}-6 \mathrm{~b}_{\mathrm{Gal}}\right), 3.39$ (s, 2H, CH${ }_{2} \mathrm{CO}$ ), 3.24 (d, 1H, J 9.2 Hz, H-28b), 3.18-3.14 (m, 1H, H-3), 2.39 (td, $\left.1 \mathrm{H}, J_{1} 5.9 \mathrm{~Hz}, J_{2} 10.8 \mathrm{~Hz}, \mathrm{H}-19\right), 2.05-0.60$ (m, 25H, CH, $\mathrm{CH}_{2}$ ), 1.68 (s, 3H, H-30), 0.99, 0.98, 0.96, 0.84, 0.76 (all s, 3H each, H-23-H-27) ppm; ${ }^{13} \mathrm{C}$ NMR (150 MHz, MeOD) $\delta_{\mathrm{C}} 168.57,151.91,146.42,126.86$, $110.24,81.77,79.75,78.48,75.82,71.51,70.49,69.49,65.15,56.90,51.92,50.23,43.80,42.18,40.12,40.01$, $38.98,38.35,35.86,35.52,31.04,30.78,28.67,28.36,28.12,26.67,22.05,19.53,19.44,16.77,16.59,16.17$, 15.30 ppm (Supplementary Materials, Table S3); IR (ATR) v: 3600-3000, 2942, 1698, 1374, 1228, 1083, $1045,879 \mathrm{~cm}^{-1}$.

Product $24 a\left(3,28-d i\left(\mathrm{OCH}_{2}\right.\right.$ TriazGlc)BN) was obtained as a white solid (63.9 $\mathrm{mg}, 87 \%$ yield); m.p.: 176-178 ${ }^{\circ} \mathrm{C} ;[\alpha]^{25}{ }_{\mathrm{D}}=+16.4(\mathrm{c} 0.5, \mathrm{MeOH})$; HRMS $\left(\mathrm{ESI}{ }^{+}\right)$: calcd for $\mathrm{C}_{48} \mathrm{H}_{76} \mathrm{~N}_{6} \mathrm{O}_{12} \mathrm{Na}\left([\mathrm{M}+\mathrm{Na}]^{+}\right)$: m/z 951.5419; found: $m / z$ 951.5441; ${ }^{1} \mathrm{H}$ NMR (600 MHz, MeOD): $\delta_{\mathrm{H}} 8.18$ i 8.14 (all s, br, $1 \mathrm{H}$ each, 2x H-5 triaz. $_{\text {) }} 5.61$ and 5.59 (all d, $1 \mathrm{H}$ each, J 8.7 Hz, 2x H-1 $\left.\mathrm{Glc}_{\mathrm{c}}\right), 4.74-4.50$ (m, 6H, H-29a, H-29b, 2x OCH$)_{2}$,

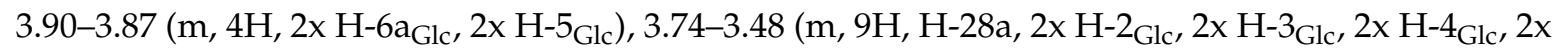
H-6b $\left.\mathrm{Glc}_{\mathrm{c}}\right), 3.23$ (d, 1H, J 9.0 Hz, H-28b), 2.98 (dd, 1H, J $\left.14.2 \mathrm{~Hz}, J_{2} 11.4 \mathrm{~Hz}, \mathrm{H}-3\right), 2.43$ (td, 1H, J $5.9 \mathrm{~Hz}, J_{2}$ 11.0 Hz, H-19), 2.00-0.65 (m, 25H, CH, CH $), 1.68$ (s, 3H, H-30), 0.99, 0.98, 0.92, 0.87, 0.75 (all s, 3H each, H-23-H-27) ppm; ${ }^{13} \mathrm{C}$ NMR (150 MHz, MeOD) $\delta_{\mathrm{C}} 151.89,146.99,146.42,124.33,124.18,110.24,88.07$, $89.65,81.20,78.64,74.11,71.00,69.82,65.36,63.50,62.49,57.23,51.93,50.25,43.85,42.25,39.85,39.96$, $39.00,38.37,35.84,35.52,31.07,30.76,28.67,28.41,28.40,26.71,22.10,19.43,18.40,16.82,16.79,16.70$, 15.32 ppm (Supplementary Materials, Table S3); IR (ATR) v: 3600-3100, 2936, 1620, 1460, 1374, 1093, $1042,896 \mathrm{~cm}^{-1}$.

Product $24 \boldsymbol{b}$ (3,28-di(OCH $\mathrm{O}_{2}$ TriazGal)BN) was obtained as a white solid (50.7 $\mathrm{mg}$, 69\% yield); m.p.: 178-179 ${ }^{\circ} \mathrm{C} ;[\alpha]^{25}{ }_{\mathrm{D}}=+22.4(\mathrm{c} 0.5, \mathrm{MeOH})$; HRMS $\left(\mathrm{ESI}^{+}\right)$: calcd for $\mathrm{C}_{48} \mathrm{H}_{77} \mathrm{~N}_{6} \mathrm{O}_{12}\left([\mathrm{M}+\mathrm{H}]^{+}\right): \mathrm{m} / \mathrm{z}$ 929.5599; found: $m / z$ 929.5621; ${ }^{1} \mathrm{H}$ NMR (600 MHz, MeOD): $\delta_{\mathrm{H}} 8.21$ and 8.18 (all s, br, $1 \mathrm{H}$ each, $2 \mathrm{x}$ H-5 triaz.), 5.57 and 5.56 (all d, $1 \mathrm{H}$ each, J $\left.9.0 \mathrm{~Hz}, 2 \times \mathrm{H}-1_{\mathrm{Gal}}\right), 4.74-4.51$ (m, 6H, 2x OCH $\left.2, \mathrm{H}-29 \mathrm{a}, \mathrm{H}-29 \mathrm{~b}\right)$, 4.15 and 4.14 (all dd t, 2H each, J 9.4 Hz, 2x H-2 $\left.{ }_{\mathrm{Gal}}\right), 3.99\left(\mathrm{~m}, 2 \mathrm{H}, 2 \mathrm{x} \mathrm{H}-4_{\mathrm{Gal}}\right), 3.85-3.69$ (m, 8H, 2x

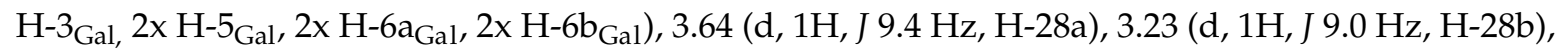
2.98 (dd, 1H, J 4.3 Hz, J2 11.8 Hz, H-3), 2.43 (td, 1H, J 5.9 Hz, J2 10.7 Hz, H-19), 2.00-0.70 (m, 25H, CH, $\mathrm{CH}_{2}$ ), 1.68 (s, 3H, H-30), 0.99, 0.98, 0.92, 0.87, 0.76 (all s, 3H each, H-23-H-27)ppm; ${ }^{13} \mathrm{C} \mathrm{NMR} \mathrm{(150} \mathrm{MHz,}$ MeOD) $\delta_{C} 151.89,147.19,146.56,123.89,123.64,110.27,90.27,88.04,80.04,79.02,75.44,71.56,71.55$, $69.77,65.38 ; 63.56,62.50,62.34,57.22,51.91,50.22,43.83,42.22,39.83,39.97,39.96,38.34,35.84,35.48$, 
$31.05,30.78,28.66,28.37,28.42,26.68,22.08,19.42,18.41,16.83,16.80,16.66,15.30$ ppm (Supplementary Materials, Table S3); IR (ATR) v: 3600-3100, 2925, 2869, 1650, 1456, 1374, 1219, 1090, 1045, $879 \mathrm{~cm}^{-1}$.

\subsection{Biological Assays}

\subsubsection{Cell Lines}

HCT 116 and MCF-7 cells were purchased from the American Type Culture Collection. NHDF cells were purchased from Lonza. All cells were cultured under standard conditions at $37^{\circ} \mathrm{C}$ in a humidified atmosphere at $5 \% \mathrm{CO}_{2}$ in DMEM/F12 medium (PAA) supplemented with $10 \%$ FBS (EURx).

\subsubsection{CCK-8 Assay}

A Cell Counting Kit-8 (CCK-8) from Bimake was used to assess cell viability. Briefly, cells were seeded in 96-well plates, with three duplicate wells in each group. Cells were treated with betulin or its derivatives and incubated for 24 or $48 \mathrm{~h}$. Then, CCK- 8 solution was added to each well and the plate was incubated for $2 \mathrm{~h}$ at $37^{\circ} \mathrm{C}$. Subsequently, the absorbance at $450 \mathrm{~nm}$ was measured using a microplate reader (Epoch, BioTek). Cell viability rate was calculated using CalcuSyn software (version 2.0, Biosoft, Cambridge, UK).

\section{Conclusions}

In conclusion, we designed and synthesized a library of novel glycoconjugates of natural pentacyclic triterpenoid (BN) by employing click chemistry. The CuAAC reactions are extensively employed in the conjugate synthesis of various organic compounds, owing to their versatility, high chemoselectivity, and mild conditions. In this study, we successfully prepared new monoand disubstituted betulin derivatives containing a sugar unit attached via a linker inclusive of the 1,2,3-triazole ring at the $\mathrm{C} 3$ and $\mathrm{C} 28$ position of the parent skeleton of $\mathrm{BN}$. We confirmed that the click chemistry approach in a simple, easy and inexpensive way leads to a wide range of products with high yield, purity, and selectivity.

The methodology developed by us extends the synthetic possibilities of modifying the betulin skeleton. Importantly, it enables the simple preparation of both mono-(modification C28) and disubstituted betulin derivatives (modification C3 and C28) with high yields. The construction of the linker connecting betulin to the sugar unit depends on the type of building blocks used. According to Strategy I, synthesis starts with the preparation of an alkyne betulin derivative, which is then clicked with a 1-azido sugar. The second option is to modify the betulin with an azide moiety and click it with propargyl O-glucoside.

Unfortunately, a preliminary cytotoxicity assay of the obtained betulin glycoconjugates showed that the addition of a sugar unit to the native betulin structure via a few selected linkers containing a 1,2,3-triazole ring is not a significant way for biological activity. Monosubstituted betulin glycoconjugates show comparable or slightly lower activity than that of betulin alone while betulin derivatives containing two sugar units protected with acetyl groups increase cell viability, which may result from the release of glucose from the tested glycoconjugates under physiological conditions. In turn, the observed lack of biological activity of deprotected betulin glycoconjugates may be due to the insufficient affinity of these compounds for glucose transporters.

3,28-O,O'-Di(2-(4-(hydroxymethyl-1H-1,2,3-triazol-1-yl)acetyl)betulin 21, modified only by introducing a fragment containing the 1,2,3-triazole system without the sugar unit, turned out to be surprisingly active. Unfortunately, it also turned out to be very toxic. This indicates that modifying the betulin backbone by introducing a 1,2,3-triazole ring significantly improves its cytotoxicity. However, further work should be done on increasing the selectivity of the obtained connections.

The obtained results show that despite the fact that the obtained betulin glycoconjugates do not show interesting antitumor activity, the idea of adding a sugar unit to the betulin backbone may, after some modifications, turn out to be correct and allow for the targeted transport of biologically 
active compounds into the tumor cells. The position used in the sugar unit for conjugation with the betulin derivative appears to be crucial for maintaining its affinity for GLUT transporters. Based on literature reports $[59,60]$, it can be assumed that the 6-OH group (the group least involved in binding to the GLUT transporter) is the most neutral position that can be modified in sugar, so as not to reduce its affinity to the transport protein on the surface of cancer cells. Due to the above, it seems advisable to undertake further research on the chemical modifications of betulin by attaching sugar through the functionalization of this position. Glycoconjugation of betulin with the use of sugar derivatives modified in the C-6 position will be carried out both with the use of 1,3-dipolar azide-alkyne cycloaddition, as well as by creating bonds that can be broken under the action of intracellular enzymes (ester, amide, or carbamate).

Supplementary Materials: The following are available online. Supporting information includes experimental procedures and spectroscopic properties of synthesized compounds $(\mathbf{4}, \mathbf{5}, \mathbf{9 - 1 4}),{ }^{1} \mathrm{H} \mathrm{NMR},{ }^{13} \mathrm{C}$ NMR spectra of all synthesized compounds (1-24) and gHSQC and FT-IR for selected compounds.

Author Contributions: Conceptualization and methodology, M.G. and G.P.-G.; synthesis and characterization of chemical compounds, M.Z., S.B. and M.K.; cytotoxicity tests, A.L.; mass spectra, K.E.; supervision, M.G. and G.P.-G.; analysis and interpretation of the results, M.G., G.P.-G., M.Z. and S.B.; writing-original draft preparation, M.G. and G.P.-G.; writing-review and editing, M.G. and G.P.-G. All authors have read and agreed to the published version of the manuscript.

Funding: This research was supported by Grant BK No. 04/020/BK/20/0122 and BKM No. 04/020/BKM20/0138 (BKM-611/RCH2/2020) as part of a targeted subsidy for conducting scientific research or development works and related tasks for the development of young scientists and participants of doctoral studie granted by Ministry of Science and Higher Education, Poland. The cytotoxicity studies was supported by BK-274/RAu1/2020.

Conflicts of Interest: The authors declare no conflict of interest.

\section{References}

1. Krasutsky, P.A. Birch bark research and development. Nat. Prod. Rep. 2006, 23, 919-942. [CrossRef] [PubMed]

2. Safe, S.; Kasiappan, R. Natural Products as Mechanism-based Anticancer Agents: Sp Transcription Factors as Targets. Phytother. Res. 2016, 30, 1723-1732. [CrossRef] [PubMed]

3. Hordyjewska, A.; Ostapiuk, A.; Horecka, A. Betulin and betulinic acid in cancer research. J. Pre-Clin. Clin. Res. 2018, 12, 72-75. [CrossRef]

4. Dutta, D.; Chakraborty, B.; Sarkar, A.; Chowdhury, C.; Das, P. A potent betulinic acid analogue ascertains an antagonistic mechanism between autophagy and proteasomal degradation pathway in HT-29 cells. BMC Cancer 2016, 16, 23. [CrossRef] [PubMed]

5. Boryczka, S.; Bębenek, E.; Wietrzyk, J.; Kempińska, K.; Jastrzębska, M.; Kusz, J.; Nowak, M. Synthesis, Structure and Cytotoxic Activity of New Acetylenic Derivatives of Betulin. Molecules 2013, 18, 4526-4543. [CrossRef]

6. Baratto, L.C.; Porsani, M.V.; Pimentel, I.C.; Netto, A.B.P.; Paschke, R.; Oliveira, B.H. Preparation of betulinic acid derivatives by chemical and biotransformation methods and determination of cytotoxicity against selected cancer cell lines. Eur. J. Med. Chem. 2013, 68, 121-131. [CrossRef]

7. Kommera, H.; Kaluđerović, G.N.; Kalbitz, J.; Dräger, B.; Paschke, R. Small structural changes of pentacyclic lupane type triterpenoid derivatives lead to significant differences in their anticancer properties. Eur. J. Med. Chem. 2010, 45, 3346-3353. [CrossRef]

8. Kommera, H.; Kaluđerović, G.N.; Dittrich, S.; Kalbitz, J.; Dräger, B.; Mueller, T.; Paschke, R. Carbamate derivatives of betulinic acid and betulin with selective cytotoxic activity. Bioorg. Med. Chem. Lett. 2010, 20, 3409-3412. [CrossRef]

9. Dangroo, N.A.; Singh, J.; Rath, S.K.; Gupta, N.; Qayum, A.; Singh, S.; Sangwan, P.L. A convergent synthesis of novel alkyne-azide cycloaddition congeners of betulinic acid as potent cytotoxic agent. Steroids 2017, 123, 1-12. [CrossRef]

10. Gauthier, C.; Legault, J.; Lebrun, M.; Dufour, P.; Pichette, A. Glycosidation of lupane-type triterpenoids as potent in vitro cytotoxic agents. Bioorg. Med. Chem. 2006, 14, 6713-6725. [CrossRef] 
11. Drag-Zalesińska, M.; Kulbacka, J.; Saczko, J.; Wysocka, T.; Zabel, M.; Surowiak, P.; Drag, M. Esters of betulin and betulinic acid with amino acids have improved water solubility and are selectively cytotoxic toward cancer cells. Bioorg. Med. Chem. Lett. 2009, 19, 4814-4817. [CrossRef] [PubMed]

12. Yang, S.-J.; Liu, M.-C.; Xiang, H.-M.; Zhao, Q.; Xue, W.; Yang, S. Synthesis and in vitro antitumor evaluation of betulin acid ester derivatives as novel apoptosis inducers. Eur. J. Med. Chem. 2015, 102, 249-255. [CrossRef] [PubMed]

13. Zhang, D.-M.; Xu, H.-G.; Wang, L.; Li, Y.-J.; Sun, P.; Wu, X.-M.; Wang, G.; Chen, W.-M.; Ye, W.-C. Betulinic Acid and its Derivatives as Potential Antitumor Agents. Med. Res. Rev. 2015, 35, 1127-1155. [CrossRef] [PubMed]

14. Zhao, H.; Liu, Z.; Liu, W.; Han, X.; Zhao, M. Betulin attenuates lung and liver injuries in sepsis. Int. Immunopharmacol. 2016, 30, 50-56. [CrossRef] [PubMed]

15. Moghaddam, M.G.; Ahmad, F.B.H.; Samzadeh-Kermani, A. Biological Activity of Betulinic Acid: A Review. Pharmacol. Pharm. 2012, 3, 119-123. [CrossRef]

16. Zhao, H.; Zheng, Q.; Hu, X.; Shen, H.; Li, F. Betulin attenuates kidney injury in septic rats through inhibiting TLR4/NF-кB signaling pathway. Life Sci. 2016, 144, 185-193. [CrossRef]

17. Fulda, S.; Kroemer, G. Targeting mitochondrial apoptosis by betulinic acid in human cancers. Drug Discov. Today 2009, 14, 885-890. [CrossRef]

18. Suman, P.; Patel, A.; Solano, L.; Jampana, G.; Gardner, Z.S.; Holt, C.M.; Jonnalagadda, S.C. Synthesis and cytotoxicity of Baylis-Hillman template derived betulinic acid-triazole conjugates. Tetrahedron 2017, 73, 4214-4226. [CrossRef]

19. Jonnalagadda, S.; Suman, P.; Morgan, D.; Seay, J. Recent Developments on the Synthesis and Applications of Betulin and Betulinic Acid Derivatives as Therapeutic Agents. Bioact. Nat. Prod. (Part O) 2017, 53, 45-84. [CrossRef]

20. Baltina, L.A.; Kazakova, O.B.; Nigmatullina, L.; Boreko, E.I.; Pavlova, N.; Nikolaeva, S.; Savinova, O.; Tolstikov, G. Lupane triterpenes and derivatives with antiviral activity. Bioorg. Med. Chem. Lett. 2003, 13, 3549-3552. [CrossRef]

21. Bori, I.D.; Hung, H.-Y.; Qian, K.; Chen, C.-H.; Morris-Natschke, S.L.; Lee, K.-H. Anti-AIDS agents 88. Anti-HIV conjugates of betulin and betulinic acid with AZT prepared via click chemistry. Tetrahedron Lett. 2012, 53, 1987-1989. [CrossRef]

22. Amiri, S.; Dastghaib, S.; Ahmadi, M.; Mehrbod, P.; Khadem, F.; Behrouj, H.; Aghanoori, M.-R.; Machaj, F.; Ghamsari, M.; Rosik, J.; et al. Betulin and its derivatives as novel compounds with different pharmacological effects. Biotechnol. Adv. 2020, 38, 107409. [CrossRef]

23. Zdzisińska, B. Właściwości lecznicze betuliny i kwasu betulinowego, składników ekstraktu z kory brzozy. Farm. Przegl. Nauk. 2010, 3, 33-39.

24. Grymel, M.; Zawojak, M.; Adamek, J. Triphenylphosphonium Analogues of Betulin and Betulinic Acid with Biological Activity: A Comprehensive Review. J. Nat. Prod. 2019, 82, 1719-1730. [CrossRef] [PubMed]

25. Pokorný, J.; Horka, V.; Sidova, V.; Urban, M. Synthesis and characterization of new conjugates of betulin diacetate and bis(triphenysilyl)betulin with substituted triazoles. Mon. Für Chem.—Chem. Mon. 2018, 149, 839-845. [CrossRef]

26. Bhunia, D.; Pallavi, P.M.C.; Bonam, S.R.; Reddy, S.A.; Verma, Y.K.; Halmuthur, S.K.M. Design, Synthesis, and Evaluation of Novel 1,2,3-Triazole-Tethered Glycolipids as Vaccine Adjuvants. Arch. Pharm. 2015, 348, 689-703. [CrossRef] [PubMed]

27. Ye, Y.; Zhang, T.; Yuan, H.; Li, D.; Lou, H.; Fan, P. Mitochondria-Targeted Lupane Triterpenoid Derivatives and Their Selective Apoptosis-Inducing Anticancer Mechanisms. J. Med. Chem. 2017, 60, 6353-6363. [CrossRef] [PubMed]

28. Dalvie, D.K.; Kalgutkar, A.S.; Khojasteh-Bakht, S.C.; Obach, R.S.; O'Donnell, J.P. Biotransformation Reactions of Five-Membered Aromatic Heterocyclic Rings. Chem. Res. Toxicol. 2002, 15, 269-299. [CrossRef]

29. Valverde, I.E.; Bauman, A.; Kluba, C.A.; Vomstein, S.; Walter, M.A.; Mindt, T.L. 1,2,3-Triazoles as Amide Bond Mimics: Triazole Scan Yields Protease-Resistant Peptidomimetics for Tumor Targeting. Angew. Chem. Int. Ed. 2013, 52, 8957-8960. [CrossRef]

30. Dheer, D.; Singh, V.; Shankar, R. Medicinal attributes of 1,2,3-triazoles: Current developments. Bioorganic Chem. 2017, 71, 30-54. [CrossRef] 
31. Thirumurugan, P.; Matosiuk, D.; Jozwiak, K. Click Chemistry for Drug Development and Diverse Chemical-Biology Applications. Chem. Rev. 2013, 113, 4905-4979. [CrossRef] [PubMed]

32. Pokorný, L.B.A.M.U.J.; Borkova, L.; Urban, M. Click Reactions in Chemistry of Triterpenes-Advances Towards Development of Potential Therapeutics. Curr. Med. Chem. 2018, 25, 636-658. [CrossRef] [PubMed]

33. Antimonova, A.N.; Petrenko, N.I.; Shakirov, M.M.; Rybalova, T.V.; Frolova, T.S.; Shul'Ts, E.E.; Kukina, T.P.; Sinitsyna, O.I.; Tolstikov, G.A. Synthesis and study of mutagenic properties of lupane triterpenoids containing 1,2,3-triazole fragments in the C-30 position. Chem. Nat. Compd. 2013, 49, 657-664. [CrossRef]

34. Bębenek, E.; Jastrzębska, M.; Kadela-Tomanek, M.; Chrobak, E.; Orzechowska, B.; Zwolińska, K.; Latocha, M.; Mertas, A.; Czuba, Z.P.; Boryczka, S. Novel Triazole Hybrids of Betulin: Synthesis and Biological Activity Profile. Molecules 2017, 22, 1876. [CrossRef] [PubMed]

35. Shi, W.; Tang, N.; Yan, W. Synthesis and cytotoxicity of triterpenoids derived from betulin and betulinic acid via click chemistry. J. Asian Nat. Prod. Res. 2015, 17, 159-169. [CrossRef] [PubMed]

36. Krawczyk, M.; Pastuch-Gawołek, G.; Mrozek-Wilczkiewicz, A.; Kuczak, M.; Skonieczna, M.; Musiol, R. Synthesis of 8-hydroxyquinoline glycoconjugates and preliminary assay of their $\beta 1,4$-GalT inhibitory and anti-cancer properties. Bioorg. Chem. 2019, 84, 326-338. [CrossRef] [PubMed]

37. Krawczyk, M.; Pastuch-Gawołek, G.; Pluta, A.; Erfurt, K.; Domiński, A.; Kurcok, P. 8-Hydroxyquinoline Glycoconjugates: Modifications in the Linker Structure and Their Effect on the Cytotoxicity of the Obtained Compounds. Molecules 2019, 24, 4181. [CrossRef]

38. Krawczyk, M.; Pastuch-Gawołek, G.; Hadasik, A.; Erfurt, K. 8-Hydroxyquinoline Glycoconjugates Containing Sulfur at the Sugar Anomeric Position-Synthesis and Preliminary Evaluation of Their Cytotoxicity. Molecules 2020, 25, 4174. [CrossRef]

39. Domiński, A.; Krawczyk, M.; Konieczny, T.; Kasprów, M.; Foryś, A.; Pastuch-Gawołek, G.; Kurcok, P. Biodegradable $\mathrm{pH}$-responsive micelles loaded with 8-hydroxyquinoline glycoconjugates for Warburg effect based tumor targeting. Eur. J. Pharm. Biopharm. 2020, 154, 317-329. [CrossRef]

40. Křen, V.; Martinkova, L. Glycosides in Medicine: "The Role of Glycosidic Residue in Biological Activity". Curr. Med. Chem. 2001, 8, 1303-1328. [CrossRef]

41. A Smith, T. Facilitative glucose transporter expression in human cancer tissue. Br. J. Biomed. Sci. 1999, 56, 285-292. [PubMed]

42. Heiden, M.G.V.; Cantley, L.C.; Thompson, C.B. Understanding the Warburg Effect: The Metabolic Requirements of Cell Proliferation. Science 2009, 324, 1029-1033. [CrossRef] [PubMed]

43. Calvaresi, E.C.; Hergenrother, P.J. Glucose conjugation for the specific targeting and treatment of cancer. Chem. Sci. 2013, 4, 2319-2333. [CrossRef] [PubMed]

44. Zhao, F.-Q. Functional Properties and Genomics of Glucose Transporters. Curr. Genom. 2007, 8, 113-128. [CrossRef]

45. Barnett, J.E.G.; Holman, G.D.; Munday, K.A. Structural requirements for binding to the sugar-transport system of the human erythrocyte. Biochem. J. 1973, 131, 211-221. [CrossRef]

46. Ma, J.; Liu, H.; Xi, Z.; Hou, J.; Li, Y.; Niu, J.; Liu, T.; Bi, S.; Wang, X.; Wang, C.; et al. Protected and De-protected Platinum(IV) Glycoconjugates With GLUT1 and OCT2-Mediated Selective Cancer Targeting: Demonstrated Enhanced Transporter-Mediated Cytotoxic Properties in vitro and in vivo. Front. Chem. 2018, 6, 386. [CrossRef]

47. Khan, I.; Guru, S.K.; Rath, S.K.; Chinthakindi, P.K.; Singh, B.; Koul, S.; Bhushan, S.; Sangwan, P.L. A novel triazole derivative of betulinic acid induces extrinsic and intrinsic apoptosis in human leukemia HL-60 cells. Eur. J. Med. Chem. 2016, 108, 104-116. [CrossRef]

48. Komissarova, N.G.; Dubovitskii, S.N.; Shitikova, O.V.; Vyrypaev, E.M.; Spirikhin, L.V.; Eropkina, E.M.; Lobova, T.G.; Eropkin, M.; Yunusov, M.S. Synthesis of Conjugates of Lupane-Type Pentacyclic Triterpenoids with 2-Aminoethane- and N-Methyl-2-Aminoethanesulfonic Acids. Assessment of in vitro Toxicity. Chem. Nat. Compd. 2017, 53, 907-914. [CrossRef]

49. Yang, Q.-R.; Qiao, W.-H.; Zhang, S.-M.; Qu, J.-P.; Liu, D.-L. Synthesis and Characterization of a New Cationic Galactolipid with Carbamate for Gene Delivery. Tenside Surfactants Deterg. 2010, 47, 294-299. [CrossRef]

50. Rajaram, H.; Palanivelu, M.K.; Arumugam, T.V.; Rao, V.M.; Shaw, P.N.; McGeary, R.P.; Ross, B.P. 'Click' assembly of glycoclusters and discovery of a trehalose analogue that retards $A \beta 40$ aggregation and inhibits A 340 -induced neurotoxicity. Bioorg. Med. Chem. Lett. 2014, 24, 4523-4528. [CrossRef] 
51. Lancuški, A.; Bossard, F.; Fort, S. Carbohydrate-Decorated PCL Fibers for Specific Protein Adhesion. Biomacromolecules 2013, 14, 1877-1884. [CrossRef] [PubMed]

52. Zemplén, G.; Pacsu, E. Über die Verseifung acetylierter Zucker und verwandter Substanzen. Berichte Dtsch. Chem. Ges. (A B Ser.) 1929, 62, 1613-1614. [CrossRef]

53. Brown, R.S.; Wahl, R.L. Overexpression of Glut-1 glucose transporter in human breast cancer. An im-munohistochemical study. Cancer 1993, 72, 2979-2985. [CrossRef]

54. Haber, R.S.; Rathan, A.; Weiser, K.R.; Pritsker, A.; Itzkowitz, S.H.; Bodian, C.; Slater, G.; Weiss, A.; Burstein, D.E. GLUT1 glucose transporter expression in colorectal carcinoma: A marker for poor progno-sis. Cancer 1998, 83, 34-40. [CrossRef]

55. Kumamoto, K.; Goto, Y.; Sekikawa, K.; Takenoshita, S.; Ishida, N.; Kawakita, M.; Kannagi, R. Increased expression of UDP-galactose transporter messenger RNA in human colon cancer tissues and its implica-tion in synthesis of Thomsen-Friedenreich antigen and sialyl Lewis A/X determinants. Cancer Res. 2001, 61, $4620-4627$.

56. Lutter, A.-H.; Scholka, J.; Richter, H.; Anderer, U. Applying XTT, WST-1, and WST-8 to human chondrocytes: A comparison of membrane-impermeable tetrazolium salts in 2D and 3D cultures. Clin. Hemorheol. Microcirc. 2017, 67, 327-342. [CrossRef]

57. Van De Waterbeemd, H.; Smith, D.A.; Jones, B.C. Lipophilicity in PK design: Methyl, ethyl, futile. J. Comput. Mol. Des. 2001, 15, 273-286. [CrossRef]

58. Lombardo, F.; Obach, R.; Shalaeva, M.Y.; Gao, F. Prediction of Volume of Distribution Values in Hu-mans for Neutral and Basic Drugs Using Physicochemical Measurements and Plasma Protein Binding Data. J. Med. Chem. 2002, 45, 2867-2876. [CrossRef]

59. Deng, D.; Xu, C.; Sun, P.; Wu, J.; Yan, C.; Hu, M.; Yan, N. Crystal structure of the human glucose transporter GLUT1. Nat. Cell Biol. 2014, 510, 121-125. [CrossRef]

60. Fernández, C.; Nieto, O.; Rivas, E.; Montenegro, G.; Fontenla, J.A.; Fernández-Mayoralas, A. Synthesis and biological studies of glycosyl dopamine derivatives as potential antiparkinsonian agents. Carbohydr. Res. 2000, 327, 353-365. [CrossRef]

Sample Availability: Samples of the compounds 15-24 are available from the authors.

Publisher's Note: MDPI stays neutral with regard to jurisdictional claims in published maps and institutional affiliations.

(C) 2020 by the authors. Licensee MDPI, Basel, Switzerland. This article is an open access article distributed under the terms and conditions of the Creative Commons Attribution (CC BY) license (http://creativecommons.org/licenses/by/4.0/). 